\title{
Viral G Protein-Coupled Receptors: Attractive Targets for Herpesvirus-Associated Diseases
}

\author{
D Timo W. M. De Groof, ${ }^{1}$ Elizabeth G. Elder, ${ }^{1}$ Marco Siderius, (D) Raimond Heukers, John H. Sinclair, and Martine J. Smit \\ In Vivo Cellular and Molecular Imaging Laboratory (ICMI), Vrije Universiteit Brussel, Brussels, Belgium (T.W.M.D.G.); Department of \\ Medicine, Addenbrooke's Hospital, University of Cambridge, Cambridge, United Kingdom (E.G.E., J.H.S.); Division of Medicinal Chemistry, \\ Faculty of Sciences, Amsterdam Institute for Molecular and Life Sciences (AIMMS), Vrije Universiteit Amsterdam, Amsterdam, The \\ Netherlands (M.S., R.H., M.J.S.); and QVQ Holding B.V., Utrecht, The Netherlands (R.H.)
}

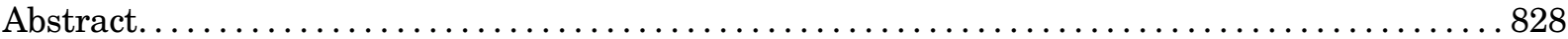

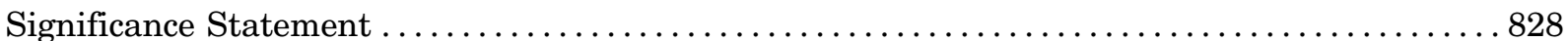

I. Family of Viral G Protein-Coupled Receptors . . . . . . . . . . . . . . . . . . . . . . . . . . . . 829

A. Herpesvirus-Encoded G Protein-Coupled Receptors $\ldots \ldots \ldots \ldots \ldots \ldots \ldots \ldots \ldots \ldots \ldots \ldots 29$

B. Pharmacological Properties of Viral G Protein-Coupled Receptors . . . . . . . . . . . . . 829

1. Homology to Chemokine Receptors. . . . . . . . . . . . . . . . . . . . . . . . . . . . . 829

2. Chemokine Scavengers ................................................. 830

3. Constitutively Active Receptors ...................................... 831

4. Heteromerization or Cross Talk with Human Chemokine Receptors . . . . . . . . . . . 831

II. Viral G Protein-Coupled Receptors in a Viral Setting . . . . . . . . . . . . . . . . . . . . . . . 831

III. Role of Viral G Protein-Coupled Receptors in Disease . . . . . . . . . . . . . . . . . . . . . 833

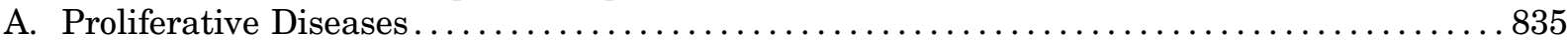

B. Cardiovascular Diseases . . . . . . . . . . . . . . . . . . . . . . . . . . . . . . . . . . . . . . . . 837

C. Post-transplant Disease ........................................... 838

IV. Viral G Protein-Coupled Receptor-Targeting Modulators and Therapeutics...............8 839

A. Small Molecules ...................................................... 839

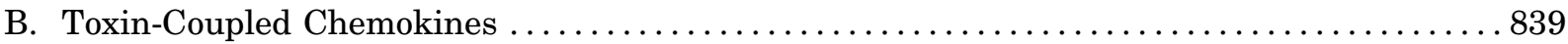

C. Viral G Protein-Coupled Receptor-Targeting Nanobodies..................... 840

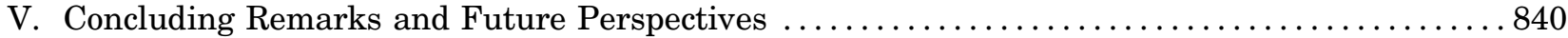

A. Pharmacological Characterization of Viral G Protein-Coupled Receptors ............... 840

B. In Vivo Model Systems . .......................................... 841

C. Therapeutic Targeting of Viral G Protein-Coupled Receptors . . . . . . . . . . . . . . 841

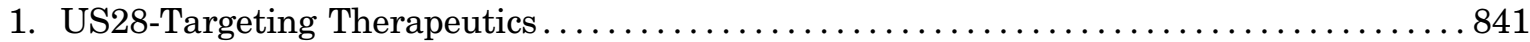

2. Other Viral G Protein-Coupled Receptors as Drug Targets .................... 842

References ....................................................... 842

Abstract - Herpesviruses are ubiquitous pathogens that establish lifelong, latent infections in their host. Spontaneous reactivation of herpesviruses is often asymptomatic or clinically manageable in healthy individuals, but reactivation events in immunocompromised or immunosuppressed individuals can lead to severe morbidity and mortality. Moreover, herpesvirus infections have been associated with multiple proliferative cardiovascular and post-transplant diseases.
Herpesviruses encode viral G protein-coupled receptors (vGPCRs) that alter the host cell by hijacking cellular pathways and play important roles in the viral life cycle and these different disease settings. In this review, we discuss the pharmacological and signaling properties of these vGPCRs, their role in the viral life cycle, and their contribution in different diseases. Because of their prominent role, vGPCRs have emerged as promising drug targets, and the potential

Address correspondence to: Prof. Dr. Martine J. Smit, Division of Medicinal Chemistry, Faculty of Sciences, Amsterdam Institute for Molecular and Life Sciences (AIMMS), Vrije Universiteit Amsterdam, De Boelelaan 1108, 1081 HZ Amsterdam, The Netherlands. E-mail: mj.smit@vu.nl

This work was supported by the Netherlands Organization for Scientific Research (NWO) [Vici Grant 016.140.657].

No author has an actual or perceived conflict of interest with the contents of this article.

${ }^{1}$ T.W.M.D.G. and E.G.E. contributed equally to this work

https://doi.org/10.1124/pharmrev.120.000186. 
of vGPCR-targeting therapeutics is being explored. Overall, these vGPCRs can be considered as attractive targets moving forward in the development of antiviral, cancer, and/or cardiovascular disease treatments.

Significance Statement__ In the last decade, herpesvirusencoded G protein-coupled receptors (GPCRs) have emerged as interesting drug targets with the growing understanding of their critical role in the viral life cycle and in different disease settings. This review presents the pharmacological properties of these viral receptors, their role in the viral life cycle and different diseases, and the emergence of therapeutics targeting viral GPCRs.

\section{Family of Viral G Protein-Coupled Receptors}

\section{A. Herpesvirus-Encoded G Protein-Coupled Receptors}

Herpesviruses are ubiquitous pathogens that establish lifelong, latent infections in their host (Vischer et al., 2006; Reid et al., 2016). One can distinguish three families of herpesviruses: $\alpha-, \gamma$-, and $\beta$-herpesviruses, also referred to as HHV-1 to HHV-8. For $\beta$ - and $\gamma$-herpesviruses, infections are usually mild or asymptomatic in healthy individuals. However, spontaneous reactivation in immunonaive, immunocompromised, or immunosuppressed individuals, such as neonates, transplant patients, and patients with AIDS, can lead to severe morbidity and mortality (Vischer et al., 2014; Reid et al., 2016). Moreover, herpesvirus infections have been associated with multiple inflammatory, cardiovascular, and oncological diseases (Vischer et al., 2014).

One key class of proteins involved in viral pathogenesis is the family of $G$ protein-coupled receptors (GPCRs). GPCRs are a superfamily of receptors involved in a wide variety of cellular processes (Rosenbaum et al., 2009; Kobilka, 2013). Because of their regulatory role, human GPCRs are involved in multiple diseases and are among the most important drug targets (Hauser et al., 2017). Chemokine receptors are a subclass of GPCRs that play a pivotal role in both regulation of the immune system and tumorigenesis (Murdoch and Finn, 2000; Dorsam and Gutkind, 2007; Ransohoff, 2009; Mollica Poeta et al., 2019). Of these, CXCR4 and CCR5 serve as coreceptors that facilitate the entry of HIV-1 virus into CD4-positive T cells (Bleul et al., 1997). Intriguingly, multiple human $\beta$ - and $\gamma$-herpesviruses encode one or more homologs of human chemokine receptors (Vischer et al., 2006). Most likely, these viral GPCRs (vGPCRs) have been acquired from the human genome and modified during evolution (Slinger et al., 2011). In the last decades, it has become clear that these vGPCRs alter the host cell by hijacking cellular pathways and play important roles in the viral life cycle. In this review, we will give a thorough overview of the GPCRs encoded by HHV-4 [also known as EpsteinBarr virus (EBV)], HHV-5 [also known as human cytomegalovirus (HCMV)], HHV-6/7 (roseoloviruses), and HHV-8 [also known as Kaposi sarcoma-associated herpesvirus (KSHV)]. We will address their pharmacological and signaling properties, role in the viral life cycle, and contribution to different disease settings. Moreover, modulators of vGPCR signaling and their therapeutic potential will be discussed. Finally, we will give our view on questions to address and future challenges to face in the field of viral GPCRs.

\section{B. Pharmacological Properties of Viral G Protein-Coupled Receptors}

1. Homology to Chemokine Receptors. To date, genes encoding for vGPCRs have been found in the genome of all human $\beta$ - and $\gamma$-herpesviruses but not in genomes of the $\alpha$-herpesviruses [HHV-1/HHV-2 (known as herpes simplex virus), HHV-3 (known as Varicella zoster)] (Fig. 1) (Vischer et al., 2006). The $\gamma$-herpesviruses EBV and KSHV each encode one vGPCR: BILF1 (EBV) and ORF74 (KSHV). In contrast, HCMV encodes four vGPCRs (US27, US28, UL33, and UL78), whereas HHV-6 and HHV-7 encode two vGPCRs (US12 and U51). Interestingly, all these viral receptors share homology with human chemokine receptors, with US28 having the highest homology (35\% with CX3CR1), whereas U51 (encoded by HHV-7) only shares $2 \%$ homology with CCR2 (Fig. 1) (de Munnik et al., 2015). Because of their homology with human chemokine receptors, multiple vGPCRs (US28, ORF74, U12, and U51 of both HHV-6 and HHV-7) bind human chemokines (Fig. 1). Similar to their human counterparts, most vGPCRs are able to bind multiple chemokines. HCMV-encoded US28 binds various chemokines from the CC family (including CCL2 and CCL5), CX3CL1, and the KSHV-encoded chemokine vCCL2 (Gao and Murphy, 1994; Kuhn et al., 1995; Kledal et al., 1997, 1998). In contrast, KSHV-encoded GPCR ORF74 binds chemokines from the CXC family. This is not surprising,

\footnotetext{
ABBREVIATIONS: ACKR3, atypical chemokine receptor 3; AIT, autoimmune thyroiditis; CCR, C-C chemokine receptor; CMV, cytomegalovirus; CREB, cAMP response element binding protein; CXCR, C-X-C chemokine receptor; CX3CR1, CX3C chemokine receptor 1; EBV, Epstein-Barr virus; FTP, fusion toxin protein; GPCR, G protein-coupled receptor; HCMV, human cytomegalovirus; HHV, human herpesvirus; HIF-1 $\alpha$, hypoxia-inducible factor 1-alpha; HIV, human immunodeficiency virus; HSCT, hematopoietic stem cell transplantation; IE, immediate early; IL, interleukin; KS, Kaposi sarcoma; KSHV, Kaposi sarcoma-associated herpesvirus; MCMV, mouse cytomegalovirus; MHC, major histocompatibility complex; NFAT, nuclear factor of activated T-cells; NF- $\kappa$ B, nuclear factor- $\kappa$ B; PE38, Pseudomonas exotoxin A; PGE2, prostaglandin E2; STAT3, signal transducer and activator of transcription 3; SVEC, seminal vesicle epithelial cells; TAZ, transcriptional coactivator with PDZ-binding motif; TCF/LEF, T-cell specific transcription factor/lymphoid enhancer binding factor; US28-Nb, US28-targeting nanobody; VEGF, vascular endothelial growth factor; vGPCR, viral G protein-coupled receptor; YAP, yes-associated protein.
} 
since ORF74 shares the highest homology with CXCR2 (27\%) (Rosenkilde et al., 1999). However, ORF74 also binds CXCL4, CXCL10, CXCL12, CCL1, CCL5, and vCCL2, which are chemokines that do not bind to CXCR2 (Arvanitakis et al., 1997; Geras-Raaka et al., 1998; Gershengorn et al., 1998). Finally, U12 and U51 (from both HHV-6 and HHV-7) are able to bind a multitude of CCL chemokines, and HHV-6-encoded U51 also binds CX3CL1, XCL1, and vCCL2 (Isegawa et al., 1998; Milne et al., 2000; Nakano et al., 2003; Tadagaki et al., 2005; Catusse et al., 2008).

Similar to human chemokine receptors, the $\mathrm{N}$ terminus of these viral receptors is essential for ligand binding (Scholten et al., 2012). In 2015, the crystal structure of US28 in complex with CX3CL1 revealed the interaction of this ligand with the $\mathrm{N}$ terminus of the receptor (Burg et al., 2015). Moreover, sulfonation of the tyrosine at position 16 on the $\mathrm{N}$ terminus of US28 has been shown to be important for chemokine binding
(Casarosa et al., 2005). However, although the $\mathrm{N}$ terminus is essential for chemokine binding in general, the various chemokines can interact differentially with the $\mathrm{N}$ terminus. Similar observations were seen for ORF74, in which sulfonation of two tyrosine residues on the $\mathrm{N}$ terminus was important for binding of CXCL1 but not CXCL10 (Feng et al., 2010). Besides interacting differentially with the receptors, different chemokines can also modulate receptor signaling in different manners, which we will discuss in more detail later on. Although multiple ligands have been found for the abovementioned receptors, no ligands for EBVencoded BILF1 and HCMV-encoded US27, UL33, and UL78 have been reported to date, designating them as orphan GPCRs.

2. Chemokine Scavengers. Although promiscuous chemokine binding to these receptors influences their signaling properties, it has also been suggested that some of these vGPCRs could act as "chemokine

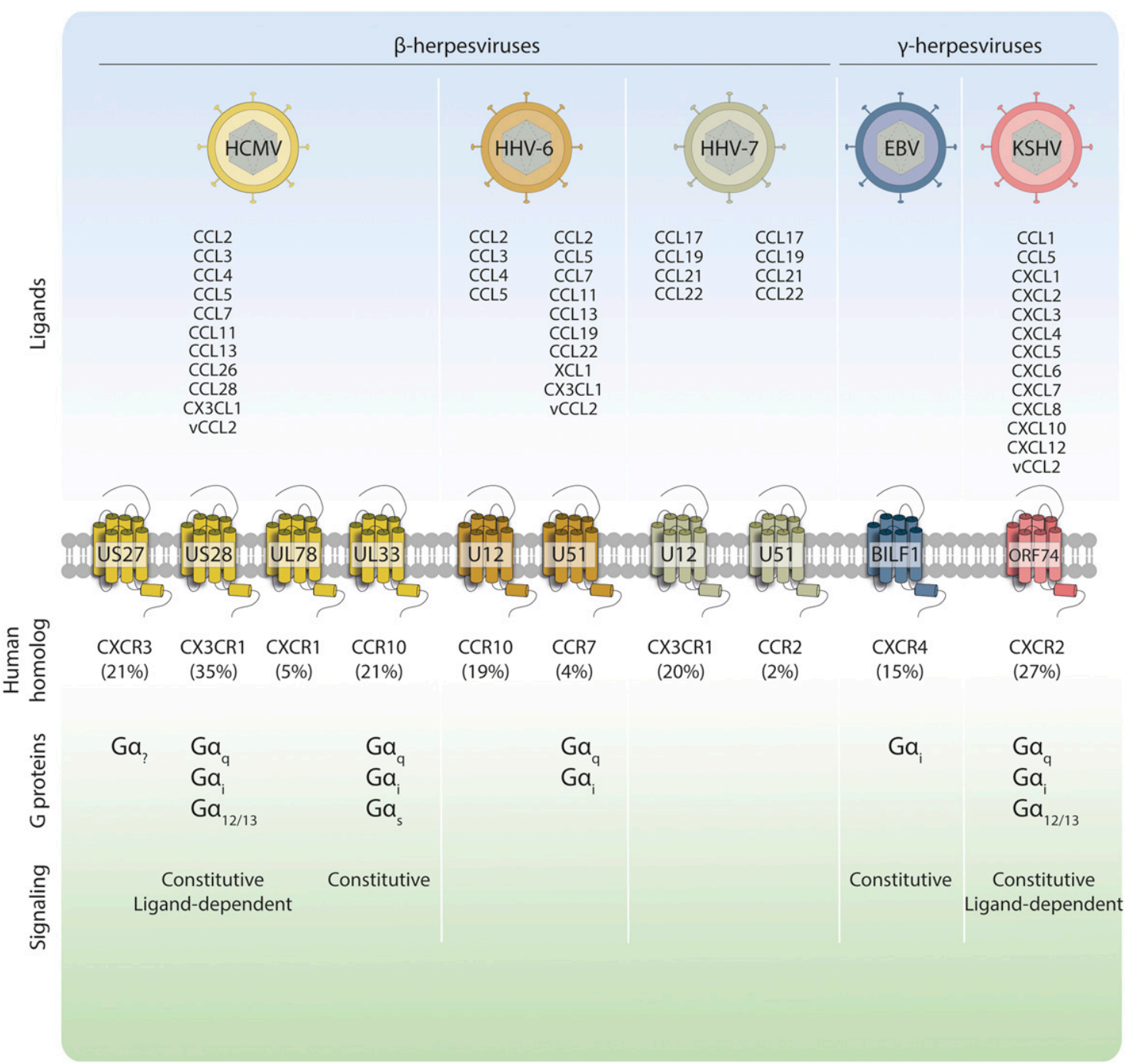

Fig. 1. Pharmacological properties of human herpesvirus-encoded GPCRs. Overview of the different viral GPCRs (colored GPCRs in the middle) encoded by the herpesviruses HCMV (HHV-5), HHV-6, HHV-7, EBV, or KSHV; their known ligands (top); and interacting G proteins (bottom). Their closest human chemokine homolog and the percentage of total homology are depicted. For each vGPCR, known signaling properties (constitutive or ligand-dependent) have been annotated. 
scavengers" or "chemokine sinks" (Bodaghi et al., 1998). For instance, extracellular levels of CCL2 and CCL5 were lower in HCMV-infected fibroblasts compared with uninfected fibroblasts, which was the result of cointernalization of these chemokines with US28 (Michelson et al., 1997; Bodaghi et al., 1998; Billstrom et al., 1999). Interestingly, US28 is a constitutively internalizing receptor, with approximately $80 \%$ of the US28 receptor population residing in perinuclear vesicles, including endosomes, multivesicular bodies, and the viral assembly compartment (Fraile-Ramos et al., 2001; Mokros et al., 2002; Droese et al., 2004). US28-mediated chemokine scavenging could reduce chemokine levels and thus minimize attraction of immune cells to HCMV-infected cells. A similar immune evasion role was proposed for HHV-6-encoded U51 in which extracellular CCL5 concentrations were lowered upon U51 expression or HHV-6 infection (Milne et al., 2000; Catusse et al., 2008). However, these reduced CCL5 levels were a consequence of reduced CCL5 expression on a transcriptional level rather than chemokine scavenging.

3. Constitutively Active Receptors. Another interesting feature of the vGPCRs, and in contrast to most human GPCRs, is their ability to signal in a ligandindependent, constitutively active manner. Examples include US28, UL33, BILF1, ORF74, and HHV6-encoded U51 (Vischer et al., 2014). Moreover, these vGPCRs signal constitutively by coupling promiscuously to several $\mathrm{G}$ proteins, such as $\mathrm{G} \alpha_{\mathrm{q}}, \mathrm{G} \alpha_{\mathrm{i}}, \mathrm{G} \alpha_{\mathrm{s}}$, and $\mathrm{G} \alpha_{12 / 13}$ (Fig. 1). The different signaling pathways activated by the different vGPCRs will be discussed in more detail in section III Role of Viral G ProteinCoupled Receptors in Disease when discussing their roles in specific disease settings.

4. Heteromerization or Cross Talk with Human Chemokine Receptors. vGPCRs can also influence cellular signaling by modulating the signaling properties of human GPCRs. Positive or negative modulation of GPCRs can occur via direct association (by heterodimerization) or via indirect mechanisms such as cross talk of signaling pathways; scavenging of shared downstream signaling proteins; or transcriptional regulation of the GPCRs, ligands, or signaling proteins (El-Asmar et al., 2005; Sohy et al., 2007, 2009; Chabre et al., 2009; Prezeau et al., 2010). BILF1 can form heterodimers with multiple chemokine receptors from the CCR and CXCR family, including CCR9, CCR10, CXCR3, and CXCR4 (Vischer et al., 2008; Nijmeijer et al., 2010). Coexpression of BILF1 and CXCR4 leads to impaired CXCR4 signaling by inhibition of CXCL12 binding to CXCR4 (Nijmeijer et al., 2010). Interestingly, BILF1 is also able to impair CXCR4 signaling as a result of scavenging of $\mathrm{G} \alpha_{\mathrm{i}}$ proteins, which could be restored upon overexpression of $\mathrm{G} \alpha_{\mathrm{i}}$ proteins (Nijmeijer et al., 2010). Similar observations have been made for the HCMV-encoded GPCRs. Coexpression of CCR1 and
US28 leads to enhanced CCR1-mediated nuclear factor $-\kappa \mathrm{B}(\mathrm{NF}-\kappa \mathrm{B})$ activation upon CCL5 binding (Bakker et al., 2004). This was dependent on constitutive US28 signaling and not CCL5 binding to US28. UL33 and UL78 are known to form heterodimers with CXCR4 and CCR5 and inhibit CCL5-mediated internalization of the CCR5 receptor (Tadagaki et al., 2012). Moreover, both receptors inhibited CCR5-mediated cell migration. However, although UL78 increases CCL5-mediated activation of CCR5, UL33 coexpression inhibits CCR5 activation upon CCL5 binding. Finally, all four HCMV-encoded GPCRs seem to influence CXCR4 signaling and expression. Coexpression of US27 and CXCR4 leads to enhanced CXCR4 expression and signaling (Arnolds et al., 2013; Boeck et al., 2018). UL33, UL78, and US28 expression, on the other hand, downregulate CXCR4 expression and signaling (Tadagaki et al., 2012; Frank et al., 2016). In the case of HHV-7, U12 and U51 have shown to potentiate CCL19- and CCL22-induced CCR4 and CCR7 signaling (Tadagaki et al., 2007).

Thus, although the vGPCRs show high homology to human chemokine receptors, their pharmacological profile is very different because of their ability to bind a broad spectrum of chemokines, constitutive activity, and promiscuous $\mathrm{G}$ protein coupling. Via binding or scavenging human chemokines, or interacting directly with human chemokine receptors or indirectly with their downstream pathways, viral GPCRs are able to tap in and modulate the endogenous chemokine/chemokine receptor system in infected cells.

\section{Viral G Protein-Coupled Receptors in a Viral Setting}

It is becoming increasingly clear that vGPCRs play important roles in both the lytic and latent life cycles of the viruses (Arfelt et al., 2015; Krishna et al., 2018; Pontejo et al., 2018; Frank et al., 2019). Table 1 summarizes the roles that have been ascribed to vGPCRs in viral settings. For many of these, it is likely that future work in more elaborate models will be needed to gain further insight into the functions of these proteins.

Elucidating the function of vGPCRs in the viral life cycle can be challenging, as some functions are only revealed in particular cell types or in vivo studies. Such a cell-type specificity of vGPCR function is nicely exemplified by the HCMV chemokine receptor homolog US28 (Krishna et al., 2018). For example, although US28 is dispensable for the in vitro infection of fibroblasts, it enhances cell-to-cell spread in epithelial and smooth muscle cells (Vieira et al., 1998; Noriega et al., 2014; Humby and O'Connor, 2015; Lollinga et al., 2017). Many groups have found US28 to be essential for latency in in vitro cultures of primary hematopoietic stem cells or myeloid lineage cells, with several 
TABLE 1

Overview of the role of vGPRs in a viral setting

\begin{tabular}{|c|c|c|c|c|}
\hline $\begin{array}{l}\text { vGPCR (Virus and Lytic } \\
\text { Expression Kinetics) }\end{array}$ & Role in Lytic Infection & Role in Latent Infection & $\begin{array}{c}\text { Role in Dissemination/Immune } \\
\text { Evasion }\end{array}$ & Orthologs \\
\hline $\begin{array}{l}\text { UL33 (HCMV late) } \\
\text { (Davis-Poynter } \\
\text { et al., 1997) }\end{array}$ & $\begin{array}{l}\text { Dispensable (Margulies } \\
\text { et al., 1996) but enhances } \\
\text { spread in multistep growth } \\
\text { analyses (van Senten et al., } \\
\text { 2020a); constitutive signaling } \\
\text { (Casarosa et al., 2003a) }\end{array}$ & $\begin{array}{c}\text { Expression detected but } \\
\text { no role established } \\
\text { (Cheng et al., 2017) }\end{array}$ & $\begin{array}{l}\text { Murine and rat models suggest } \\
\text { roles in replication in salivary } \\
\text { gland, latency, and dendritic cell } \\
\text { trafficking (Frank et al., 2019) }\end{array}$ & Murine - M33 rat - R33 \\
\hline $\begin{array}{l}\text { UL78 (HCMV early) } \\
\text { (Wagner et al., } \\
\text { 2012) }\end{array}$ & $\begin{array}{l}\text { Dispensable (Michel et al., } \\
\text { 2005) but important for entry } \\
\text { into epithelial cells and } \\
\text { replication in epi/endothelial } \\
\text { cells (O'Connor and Shenk, } \\
\text { 2012) }\end{array}$ & $\begin{array}{l}\text { Expression detected but } \\
\text { no role established } \\
\text { (Cheng et al., 2017) }\end{array}$ & $\begin{array}{l}\text { Murine and rat models suggest } \\
\text { importance in replication in } \\
\text { specific cell types in vivo } \\
\text { (Oliveira and Shenk, 2001; } \\
\text { Kaptein et al., 2003) }\end{array}$ & Murine - M78 rat - R78 \\
\hline $\begin{array}{l}\text { US27 (HCMV late) } \\
\text { (Vieira et al., 1998; } \\
\text { Chambers et al., } \\
\text { 1999; Margulies } \\
\text { and Gibson, 2007) }\end{array}$ & $\begin{array}{l}\text { Important for extracellular } \\
\text { spread (O'Connor and Shenk, } \\
\text { 2011); promotion of cell } \\
\text { growth and survival (Tu and } \\
\text { Spencer, 2014) }\end{array}$ & $\begin{array}{l}\text { Expression not detected } \\
\text { (Cheng et al., 2017; } \\
\text { Shnayder et al., 2018) }\end{array}$ & $\begin{array}{l}\text { Highly conserved but in vivo role } \\
\text { unclear (Stegman and } \\
\text { Margulies, 2017; Frank et al., } \\
\text { 2019) }\end{array}$ & $\begin{array}{c}\text { Present in primate CMVs but } \\
\text { not rodent CMVs (Alcendor } \\
\text { et al., 2009) }\end{array}$ \\
\hline $\begin{array}{l}\text { US28 (HCMV early) } \\
\text { (Vieira et al., 1998) }\end{array}$ & $\begin{array}{l}\text { Dispensable (Vieira et al., } \\
\text { 1998; Humby and O'Connor, } \\
\text { 2015); enhances infection of } \\
\text { epithelial cells and smooth } \\
\text { muscle cells (Noriega et al., } \\
\text { 2014; Lollinga et al., 2017); } \\
\text { constitutive and ligand- } \\
\text { induced signaling (Krishna } \\
\text { et al., 2018) }\end{array}$ & $\begin{array}{l}\text { Required for latency in } \\
\text { in vitro models (Humby } \\
\text { and O'Connor, 2015; } \\
\text { Krishna et al., 2017a; } \\
\text { Zhu et al., 2018); } \\
\text { required for reactivation } \\
\text { in humanized mice } \\
\text { (Crawford et al., 2019) }\end{array}$ & $\begin{array}{l}\text { Induces cell migration and } \\
\text { adhesion (Melnychuk et al., } \\
\text { 2004; Vomaske et al., 2009; } \\
\text { Hjorto et al., 2013; Wu and } \\
\text { Miller, 2016; Farrell et al., 2018; } \\
\text { Aslam et al., 2019); chemokine } \\
\text { sink (Randolph-Habecker et al., } \\
\text { 2002); myeloid differentiation } \\
\text { (Zhu et al., 2018; Crawford et al., } \\
\text { 2019) }\end{array}$ & $\begin{array}{l}\text { Present in primate CMVs but } \\
\text { not rodent CMVs (Alcendor } \\
\text { et al., 2009); five rhesus CMV } \\
\text { US28 homologs characterized }\end{array}$ \\
\hline $\begin{array}{l}\text { U12 (HHV-6A/B late) } \\
\text { (Isegawa et al., } \\
\text { 1998) }\end{array}$ & $\begin{array}{l}\text { Ligand-induced signaling } \\
\text { (Isegawa et al., 1998); likely } \\
\text { dispensable for viral } \\
\text { replication (Dominguez et al., } \\
\text { 1999) }\end{array}$ & Unknown & Unknown & $\begin{array}{l}\text { Homologs not functionally } \\
\text { characterized }\end{array}$ \\
\hline $\begin{array}{l}\text { U51 (HHV-6A/B early) } \\
\text { (Menotti et al., } \\
\text { 1999) }\end{array}$ & $\begin{array}{l}\text { Enhances viral replication } \\
\text { (Zhen et al., 2005) }\end{array}$ & Unknown & $\begin{array}{c}\text { Leukocyte migration/ } \\
\text { immunomodulation (Catusse } \\
\text { et al., 2008) }\end{array}$ & $\begin{array}{l}\text { Homologs not functionally } \\
\text { characterized }\end{array}$ \\
\hline U12 (HHV-7) & $\begin{array}{l}\text { Ligand-induced signaling } \\
\text { (Nakano et al., 2003; } \\
\text { Tadagaki et al., 2005) }\end{array}$ & Unknown & Unknown & $\begin{array}{l}\text { Homologs not functionally } \\
\text { characterized }\end{array}$ \\
\hline U51 (HHV-7) & $\begin{array}{l}\text { Ligand-induced signaling } \\
\text { (Tadagaki et al., 2005) }\end{array}$ & Unknown & Unknown & $\begin{array}{l}\text { Homologs not functionally } \\
\text { characterized }\end{array}$ \\
\hline BILF1 (EBV early) & $\begin{array}{c}\text { Immune evasion (cell } \\
\text { intrinsic and extrinsic) } \\
\text { (Arfelt et al., 2015; } \\
\text { Morales-Sánchez and } \\
\text { Fuentes-Panana, 2018) not } \\
\text { required for lytic replication } \\
\text { (Zuo et al., 2011) }\end{array}$ & $\begin{array}{l}\text { Expressed at low levels } \\
\text { (Tierney et al., 2015) }\end{array}$ & $\begin{array}{c}\text { Likely immune evasion } \\
\text { including evasion of cytotoxic } \\
\text { T-cell recognition }\end{array}$ & $\begin{array}{c}\text { BILF1 homologs } \\
\text { characterized in primate } \\
\text { lymphocryptoviruses (Spiess } \\
\text { et al., 2015a) }\end{array}$ \\
\hline $\begin{array}{r}\text { ORF74 (KSHV early) } \\
\text { (Chiou et al., 2002) }\end{array}$ & $\begin{array}{l}\text { Necessary for efficient lytic } \\
\text { replication (Sandford et al., } \\
2009 \text { ) }\end{array}$ & $\begin{array}{l}\text { Expression kept at low } \\
\text { levels (Vischer et al., } \\
2014 \text { ); possible } \\
\text { reactivation from } \\
\text { latency (Chen et al., } \\
\text { 2009; Sandford et al., } \\
\text { 2009) }\end{array}$ & $\begin{array}{l}\text { Murine models indicate } \\
\text { important roles in reactivation } \\
\text { from latency (Moorman et al., } \\
\text { 2003; López-Rodríguez et al., } \\
\text { 2019) }\end{array}$ & $\begin{array}{c}\text { MHV68 ORF74 (Virgin et al., } \\
\text { 1997) }\end{array}$ \\
\hline
\end{tabular}

mechanistic studies additionally identifying US28 signaling or ligand binding as contributory factors to latency establishment and/or maintenance (Humby and O'Connor, 2015; Krishna et al., 2017a, 2019, 2020; Zhu et al., 2018; Crawford et al., 2019; Elder et al., 2019). Potential roles for US28 in vivo have been postulated, including smooth muscle cell and myeloid cell migration (Waldhoer et al., 2002; Melnychuk et al., 2004; Vomaske et al., 2009), adhesion to endothelial cells (Wu and Miller, 2016; Aslam et al., 2019), immune evasion (Randolph-Habecker et al., 2002; Elder et al., 2019), and myeloid differentiation (Zhu et al., 2018; Crawford et al., 2019).
Analyses of murine, rat, guinea pig, and rhesus cytomegaloviruses are also yielding an understanding of the roles of CMV GPCRs in vivo (Beisser et al., 1998; Kaptein et al., 2003; Case et al., 2008; Alcendor et al., 2009; Cardin et al., 2009; Takeda et al., 2018; Frank et al., 2019). The HCMV GPCRs UL33 and UL78 are well conserved across mammalian species, but homologs of US27 and US28 are only found in primate CMVs, with five homologs of US28 in rhesus CMV (Alcendor et al., 2009). Thus, it is not straightforward to assess the conservation of function of the CMV GPCRs. For example, deletion of M33, the murine homolog of UL33, from mouse CMV (MCMV) produced a virus with 
an attenuated phenotype in vivo, with ablated salivary gland replication when using the intraperitoneal infection route and reduced dendritic cell trafficking after intranasal infection (Case et al., 2008; Farrell et al., 2011, 2018). Substitution of HCMV US28 for MCMV M33 could only partially restore aspects of both phenotypes, whereas HCMV UL33 could complement the salivary gland replication phenotype (Case et al., 2008; Farrell et al., 2011, 2018). It is therefore highly credible that US28 plays important roles in in vivo processes such as viral dissemination, but the lack of tractable small-animal models of HCMV does not allow us to completely dissect the roles of each vGPCR in human host-specific viruses.

The KSHV vGPCR ORF74 has an important role in lytic replication. The promoter of ORF74 is likely responsive to the lytic switch protein called Replication and Transcription Activator (known as RTA). Depletion of ORF74 reduced viral titers in a reactivation setting in primary effusion lymphoma and endothelial cells (Chiou et al., 2002; Zhang et al., 2005; Chen et al., 2009; Sandford et al., 2009; López-Rodríguez et al., 2019). Furthermore, although ORF74 is dispensable for acute infection, deletion of ORF74 in MHV68 leads to a failure of reactivation during in vivo infection of mice (Moorman et al., 2003; López-Rodríguez et al., 2019). The constitutive signaling of ORF74 contributes to successful infection via both autocrine and paracrine mechanisms, for example, by sustained expression of replication and transcription activator via protein kinase $\mathrm{C}$ activation in lytically infected cells (Bottero et al., 2009), and maintenance of latent gene expression in bystander cells by cyclooxygenase 2 and prostaglandin E2 induction (Sharma-Walia et al., 2006; Shelby et al., 2007; Bottero et al., 2009). Further paracrine roles for ORF74 have been elucidated in the context of oncogenesis (discussed later in section III Role of Viral $G$ Protein-Coupled Receptors in Disease). Nonetheless, it is not entirely clear what the consequences of, for example, increased angiogenic factor secretion might be in a nonlesion context. Additional studies using elegant tissue or animal models are needed to understand these phenomena.

Clearly, there is more to be understood about the vGPCRs during viral infections-perhaps no more so than for the HHV-6A/B and HHV-7 vGPCRs U12 and U51, for which only a little is known about their roles in latent or lytic viral life cycles. U51 is a positive regulator of HHV-6A replication that might be related to cell-cell spread and may induce leukocyte migration in response to chemokine gradients (Zhen et al., 2005; Catusse et al., 2008). Recently, the presence of HHV-6, and vGPCRs U12 and U51 mRNA, was detected in thyroid gland tissues of patients with autoimmune thyroiditis (AIT) (Sultanova et al., 2020). Moreover, CCL5 levels in blood plasma were lowered in patients with AIT in which U12 and U51 gene expression was detected, indicating a potential role for these vGPCRs in influencing CCL5 signaling in AIT. Otherwise, our knowledge of the functions of U12 and U51 is limited to chemokine binding and signaling, often known only in the context of exogenous expression of the receptors in isolation (Davis-Poynter et al., 1997; Isegawa et al., 1998; Menotti et al., 1999; Milne et al., 2000; Nakano et al., 2003; Tadagaki et al., 2005; Fitzsimons et al., 2006). Since vGPCRs dimerize and couple with host and viral proteins (described in section I Family of Viral G Protein-Coupled Receptors), a complete understanding of vGPCR function will likely require analyses of endogenous protein levels in the context of viral infection.

The EBV vGPCR BILF1 almost certainly contributes to immunomodulation and immune evasion in the infected host (Arfelt et al., 2015; Morales-Sánchez and Fuentes-Panana, 2018). Despite the absence of ligand binding activity, BILF1 reduces the levels of antiviral protein kinase $R$ when expressed exogenously (Beisser et al., 2005). Further immunomodulatory roles for BILF1 have been proposed, including interference with CXCR4 signaling and upregulation of leukocyte adhesion molecule intercellular adhesion molecule 1 (ICAM1) expression (Nijmeijer et al., 2010; Guo et al., 2020). More widely characterized is the ability of BILF1 to downregulate cell-surface MHC class I molecule expression via a direct interaction between BILF1 and MHC molecules, leading to reduced T-cell recognition (Zuo et al., 2009, 2011; Griffin et al., 2013; Fares et al., 2019). Interestingly, mutations in the $\mathrm{N}$ terminus and third extracellular loop of BILF1 ablated MHC class I downregulation but not constitutive GPCR signaling (Fares et al., 2019). This suggests that there are further functions of BILF1 related to signaling that are yet to be elucidated. Like many other herpesviral immune modulators, there is no apparent requirement of BILF1 for lytic replication, perhaps indicating that BILF1 constitutive signaling does not play a significant role in activation of lytic viral gene expression (Zuo et al., 2011). Further studies, particularly making use of BILF1 deletions and mutations in the context of viral infection, are required to provide increased insight into its role in viral infection.

\section{Role of Viral G Protein-Coupled Receptors in Disease}

Infections with most herpesviruses are generally asymptomatic in healthy individuals. Nonetheless, these viruses can be opportunistic pathogens and take advantage when the immune system is compromised. Consequently, herpesvirus infections are associated with various diseases, including proliferative diseases, transplant-associated diseases, inflammatory diseases, and cardiovascular diseases. In view of the prominent role of human GPCRs in multiple (patho)physiologic 
A Proliferative diseases

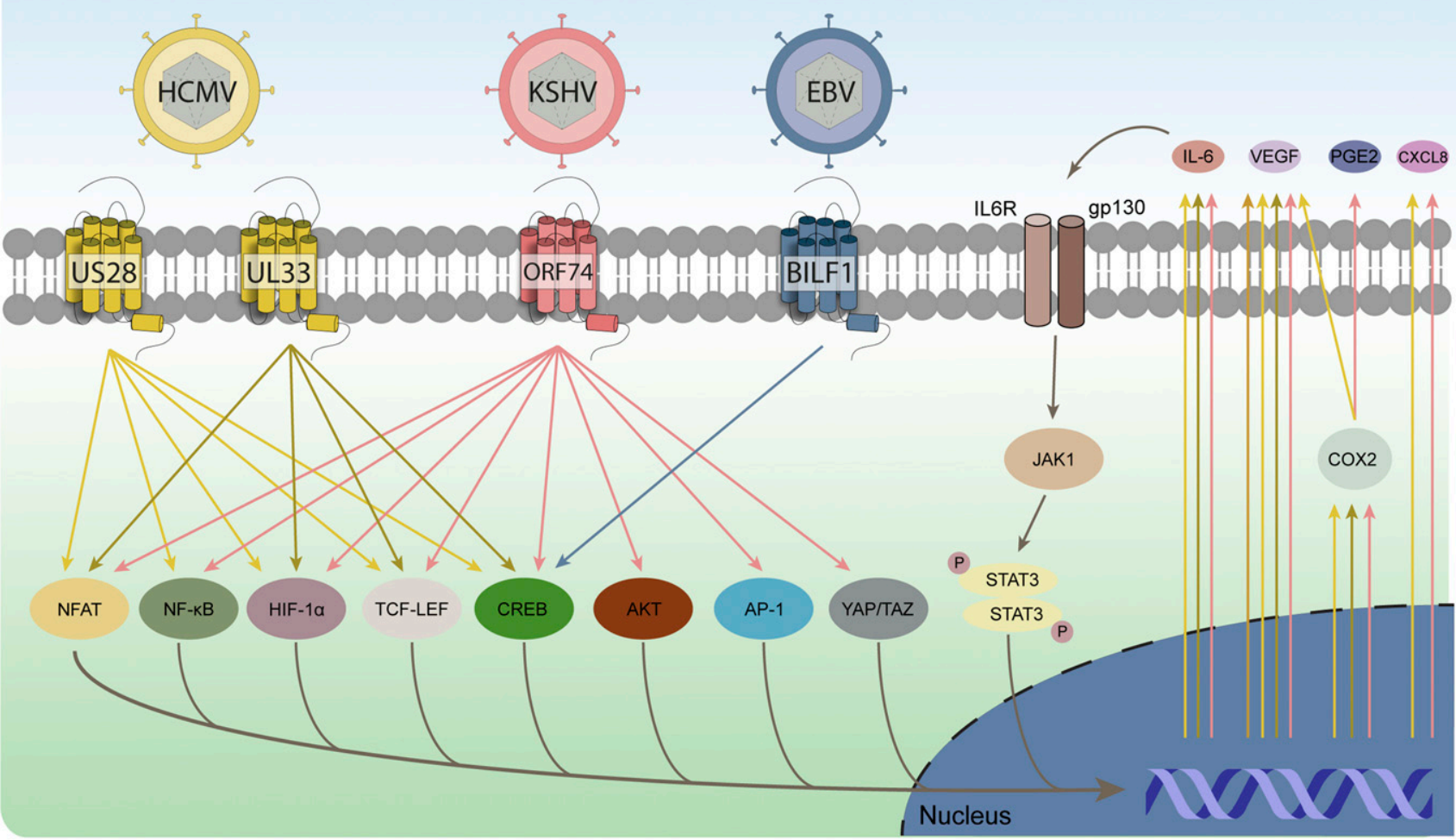

\section{B Cardiovascular diseases}

\section{Post-transplant diseases}
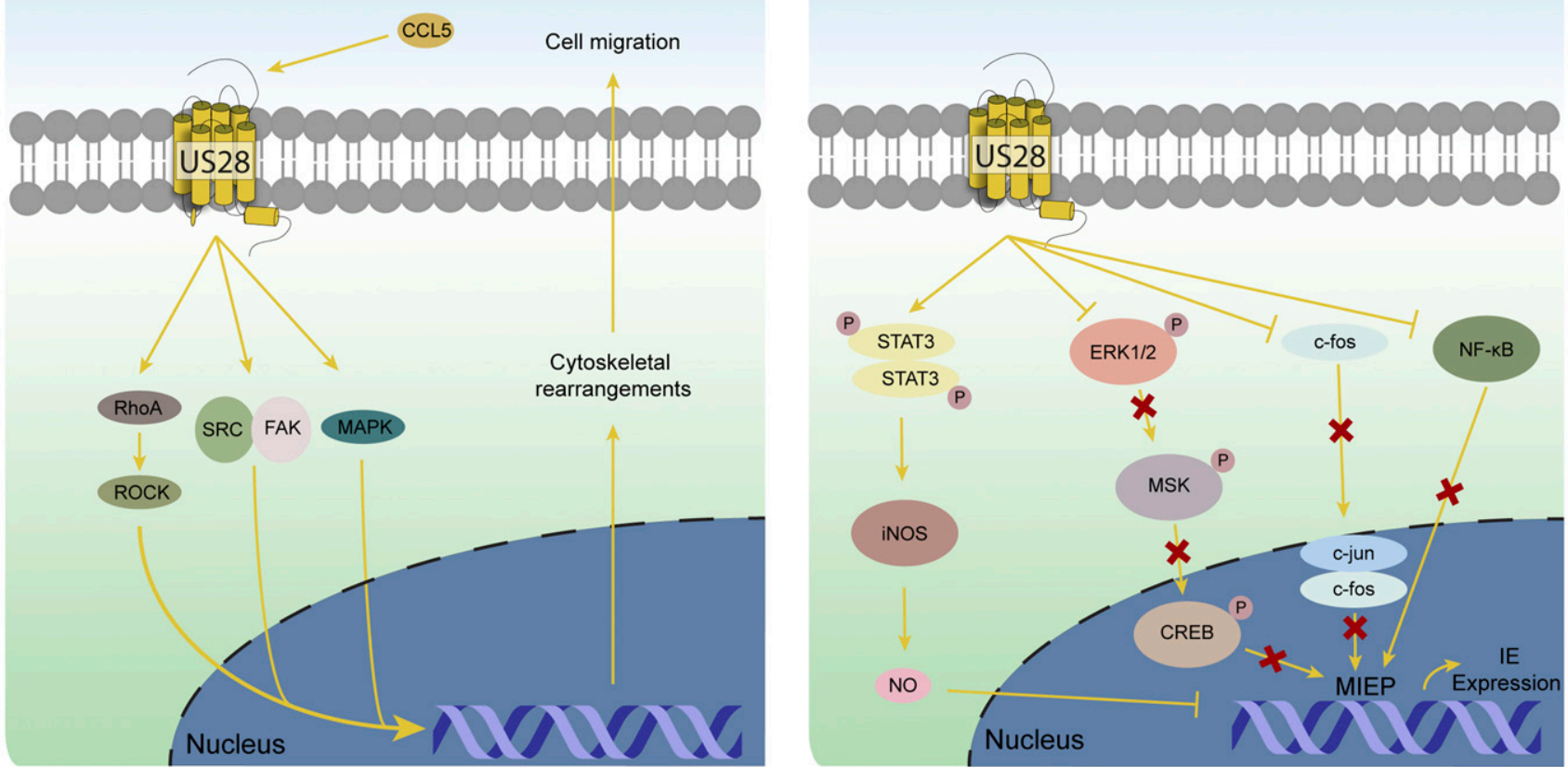

Fig. 2. Major signaling pathways activated by human herpesvirus-encoded GPCRs in different disease settings. (A) Overview of the different (proliferative) signaling pathways activated by US28 (yellow arrows), UL33 (dark yellow arrows), ORF74 (pink arrows), and BILF1 (blue arrows) in cancer cells. Activation of some of these pathways results in the activation of cyclooxygenase 2 (COX2) and secretion of IL-6, PGE2, and VEGF. Secreted IL-6 activates the IL-6 receptor [consisting of the IL-6 receptor subunit (IL6R) and glycoprotein 130 (gp130)] . Activation of the IL-6 receptor results in the stimulation of the Janus kinase 1 (JAK1)-STAT3 pathway, leading to a feed-forward loop. Activation of these pathways contributes to several cancer hallmarks, including sustained proliferative signaling, tissue invasion, angiogenesis, and immune evasion. (B) Binding of CCL5 to US28 activates several pathways that result in smooth muscle cell migration in cardiovascular diseases. CCL5-mediated activation of US28 stimulates the Rho-associated protein kinase (ROCK) pathway and mitogen-activated protein kinase (MAPK) pathway and the formation of Src-mediated focal adhesion kinase (FAK) complexes, resulting in cytoskeletal changes, cell detachment, and subsequent cell migration. (C) US28 suppresses the major 
processes and diseases, it is not surprising that herpesvirus-encoded GPCRs also play a key role in several of the processes underlying herpesvirus-associated diseases (Fig. 2).

\section{A. Proliferative Diseases}

The role of KSHV, EBV, and HCMV in different types of cancer has been a major point of discussion in the last decades. Although the role of KSHV and EBV in cancer development is clear, the role for HCMV in (certain) cancer types is less pronounced and is still being investigated. However, numerous studies have also shown, or suggested, an involvement of herpesvirusencoded GPCRs in the initiation and/or progression of different types of cancer over the last couple of years (Mesri et al., 2010; Jha et al., 2016; Nauclér et al., 2019). In this paragraph, we will give a general overview of the effects of several vGPCRs in an oncological context. An in-depth analysis of the different signaling pathways activated by vGPCRs related to the cancer hallmarks has been provided recently (van Senten et al., 2020b). Although we will focus on the role of vGPCRs, it is important to note that these are not the only viral proteins that (may) contribute to cancer initiation and/or progression. Some other examples of viral proteins that are involved include latency-associated nuclear antigen (LANA), v-cyclin, and viral B-cell lymphoma-2 (BCL2) in the case of KSHV; EpsteinBarr nuclear antigen 1 (EBNA1), latent membrane protein 1 (LMP1), and Epstein-Barr virus-encoded small RNAs (EBERs) in the case of EBV; and HCMVencoded IE proteins pp65 and pp71. The role of all different herpesvirus-encoded proteins has been described in detail in other review articles (Mesri et al., 2010; Jha et al., 2016; Nauclér et al., 2019).

As for the contribution of herpesviruses in cancer, a role for KSHV is well established. KSHV infection can cause primary effusion lymphoma (a type of diffuse large B-cell lymphoma) and multicentric Castleman disease (involving hyperproliferation of B cells in lymph nodes), which are two rare lymphoproliferative diseases (Chen et al., 2007; Cesarman, 2014). Moreover, KSHV infection can also lead to the onset of Kaposi sarcoma (KS) lesions, a type of cancer often occurring in patients with AIDS (Chang et al., 1994). KSHV-induced KS lesions are often associated with immunocompromised individuals, indicating a potential involvement of KSHV reactivation in their development (Casper and Wald, 2007). KS lesions are generally observed as painless red or purple skin marks. However, lesions can also occur in the mouth, airways, or gastrointestinal tracts of patients, resulting in more serious symptoms, such as difficulty with eating, speaking, and breathing and malabsorption or intestinal obstruction (Garay et al., 1987; Danzig et al., 1991; Radu and Pantanowitz, 2013). Interestingly, ORF74 expression has been detected in KS lesions and primary effusion lymphomas (Cesarman et al., 1996; Staskus et al., 1997). This may seem contradictory, as ORF74 is a lytic gene (Liang and Ganem, 2004), yet lytic proteins such as ORF74 are believed to contribute to tumor progression through enhanced inflammation, survival, and immunomodulation (Morales-Sanchez and Fuentes-Panana, 2018). ORF74 is only expressed in a subset of cells in KS lesions of patients and animal models. Its expression in in vitro and in vivo models coincides with the expression of paracrine factors and, consequently, tumor initiation and maintenance (Pati et al., 2001; Montaner et al., 2004, 2006; Martin and Gutkind, 2009).

Ligand-independent signaling of ORF74 leads to the activation of multiple $G$ protein signaling pathways, including phosphoinositide 3-kinase (PI3K)-protein kinase B (AKT) and extracellular signal-regulated kinase (MAPK1/ERK) pathways, resulting in the activation of several transcription factors, including $\mathrm{NF}-\kappa \mathrm{B}, \mathrm{NFAT}$, and HIF-1 $\alpha$ (Sodhi et al., 2000; Shepard et al., 2001; Smit et al., 2002; Montaner et al., 2004; Shelby et al., 2007). As a result, ORF74 activates several oncogenic pathways, also promoting secretion of proliferative and proangiogenic paracrine factors such as VEGF, IL-6, and PGE2. Consequently, ORF74 can, for example, induce the transformation of endothelial cells (Bais et al., 2003). These results were further corroborated in vivo with transgenic ORF74-expressing mice developing KS-like lesions (Yang et al., 2000; Guo et al., 2003). Moreover, ORF74 activates YAP/TAZ, which are coactivators interacting with the transcriptional enhanced associate domain family of DNA-binding factors in a $\mathrm{G} \alpha_{\mathrm{q}^{-}}$and $\mathrm{G} \alpha_{12 / 13}$-dependent manner, resulting in dysregulation of the Hippo-YAP/TAZ pathway, which promotes proliferation and migration in SVEC and HEK293A cells (Liu et al., 2015). The Hippo-YAP/TAZ signaling pathway plays an important role in organ growth and development, and dysregulation of this pathway is associated with cancer stem cells stemness (van Senten et al., 2020b). ORF74-mediated transformation and survival in SVEC cells was impaired upon treatment with verteporfin, a YAP inhibitor (Liu et al., 2015). Besides the constitutive signaling of ORF74, studies have shown that ligand-induced signaling of ORF74 can also play a role in tumorigenesis (Holst et al., 2001; Feng et al., 2010). Expression of ORF74

immediate early promotor (MIEP) and subsequent immediate early (IE) gene expression in early myeloid cells. US28 attenuates several pathways, including the CREB, activator protein 1 (AP-1) (via c-fos), and nuclear factor- $\kappa \mathrm{B}(\mathrm{NF}-\kappa \mathrm{B})$ pathway. CREB-mediated signaling is inhibited by attentuation of the phosphorylation of extracellular signal-regulated kinase (ERK) $1 / 2$, mitogen- and stress-activated kinase (MSK) 1 and CREB. By activation of the STAT3-inducible nitric oxide synthase (iNOS) pathway, US28 activation leads to increased nitric oxide (NO) levels, resulting in suppression of the MIEP. By suppression of MIEP, no IE expression is observed, resulting in a latent infection in early myeloid cells. 
mutants unresponsive to agonist stimulation in transgenic mice resulted in a smaller fraction of mice developing KS-like lesions. These studies combined show the importance of both ligand-dependent and -independent signaling of ORF74 in tumorigenesis.

EBV has been implicated in multiple cancer types, including Burkitt lymphoma, (non-)Hodgkin lymphoma, epithelial cell tumors, gastric carcinoma, and nasopharyngeal carcinoma (Pearson, 1993; Thompson and Kurzrock, 2004; Fukayama, 2010). However, the precise role of EBV in Burkitt lymphoma remains not fully understood, as viral gene expression seems to be restricted in Burkitt lymphoma cells in primary tissues but not in culture conditions (Gregory et al., 1990). Interestingly, expression of EBV-encoded BILF1 has been detected at low levels in Burkitt lymphoma cell lines during latency as well as in EBV-transformed cell lines (Beisser et al., 2005; Quinn et al., 2014; Tierney et al., 2015). In vitro and in vivo experiments have shown that BILF1 expression induces tumorigenesis through constitutive signaling via $\mathrm{G} \alpha_{\mathrm{i}}$, resulting in activation of cAMP response element (CRE)-mediated transcription (Beisser et al., 2005; Lyngaa et al., 2010). Although not apparent in relevant Burkitt lymphoma and lymphoblastoid B-cell lines, some studies have indicated activation of NF- $\kappa \mathrm{B}-$ mediated signaling in COS-7 and HEK293T cells by BILF1 (Beisser et al., 2005; Paulsen et al., 2005; Spiess et al., 2015a). Although BILF1-induced tumorigenesis is dependent on the constitutive activity of BILF1, it is not solely dependent on $\mathrm{G}$ protein-dependent signaling. Expression of BILF1 mutants unable to couple to G proteins in a xenograft mouse model still induced tumor formation, indicating a role for (constitutively active) G proteinindependent signaling of BILF1 (Lyngaa et al., 2010). As described in section II Viral G Protein-Coupled Receptors in a Viral Setting, BILF1 induces downregulation of MHC class I surface expression (Griffin et al., 2013). Downregulation of human leukocyte antigen (HLA) class molecules results in the modulation of antigen presentation to cytotoxic $\mathrm{T}$ cells and could be beneficial for immune evasion of EBV-infected cancer cells.

In addition, HCMV has also been associated with multiple cancers, including colon cancer, prostate cancer, breast cancer, and glioma (Cobbs et al., 2002; Harkins et al., 2002; Samanta et al., 2003; Mitchell et al., 2008; Michaelis et al., 2009; Baryawno et al., 2011). In particular, the link between HCMV and glioblastoma, the most common and aggressive form of malignant brain tumors, has been investigated extensively. The presence of HCMV is still debated, since multiple studies were able to detect HCMV nucleic acids and proteins in patient samples, whereas other studies were not (Dziurzynski et al., 2012). This could be explained by the use of distinct detection techniques associated with differences in detection sensitivity and handling of different cancer cell subtypes during divergent stages of tumor progression. Another explanation that has been proposed involves a "hit-and-run" mechanism whereby HCMV genes are transiently expressed to induce a transformed cellular state (Shen et al., 1997). Unlike EBV and KSHV, HCMV is generally believed to play an oncomodulatory role by enhancing progression of cancers, rather than being an oncogenic virus (Dziurzynski et al., 2012). However, a recent study did show that the clinical HCMV strain HCMV-DB was able to transform primary human mammary epithelial cells by dysregulation of telomerase, p53, and retinoblastoma protein (RB), resulting in the induction of tumor formation in vitro and in vivo (Kumar et al., 2018). These results imply that some strains of HCMV may be more oncogenic than others. Over the years, extensive research has been done on the effects of HCMV on the different hallmarks and stages of cancer. Interestingly, HCMV infection was found to result in the activation of many different oncogenic processes. HCMV can lead to survival of cancer stem cells; induction of DNA damage; induction of inflammatory cytokines (including CCL2, CCL3, CCL5, interferon- $\gamma$ (IFN), tumor necrosis factor- $\alpha$ (TNF), IL4, and IL-18); and expression of oncogenic pathways such as COX-2, NF- $\mathrm{B}$, and the STAT3-IL-6 pathway, promoting tumor initiation, chronic inflammation, angiogenesis, and proliferation (Shen et al., 1997; Fortunato and Spector, 1998, 2003; Maussang et al., 2009; Siew et al., 2009; Slinger et al., 2010; Soroceanu et al., 2015; Fornara et al., 2016; Liu et al., 2017; Clement and Humphreys, 2019). In addition, several studies have also shown an effect of HCMV on tumor invasiveness and aggressiveness by affecting mesenchymalepithelial transition and epithelial-mesenchymal transition. In addition, immunomodulatory effects of HCMV, including promotion of M2 macrophage maturation, inhibition of dendritic cell maturation, and modulation of the activity of monocytes, have been reported (Cobbs et al., 2008; Dziurzynski et al., 2011; Fiallos et al., 2014; Avdic et al., 2016; Oberstein and Shenk, 2017; Teo et al., 2017; Moussawi et al., 2018). In a recent study using a murine glioblastoma model, MCMV reactivation was observed in glioblastoma cells and intratumoral pericytes, resulting in significant reduction in survival rate (as opposed to uninfected animals) (Krenzlin et al., 2019). This effect could be counteracted upon treatment of mice with the antiviral drug cidofovir, showing the oncomodulatory role of CMV in glioblastoma.

US28 is one of the HCMV-encoded vGPCRs that has been detected in patient material of HCMV-positive patients with cancer, including patients with colorectal cancer and glioblastoma (Slinger et al., 2010; Soroceanu et al., 2011; Cai et al., 2016; Heukers et al., 2018). Over the years, it has become clear that US28 plays a predominant role in the oncomodulatory behavior of 
HCMV. In the last decade, extensive research has been performed on the role of US28 signaling in cancer (mostly glioblastoma). US28 constitutively activates, in a primarily $\mathrm{G} \alpha_{\mathrm{q}}$-dependent manner, multiple oncogenic pathways, including the NF- $\kappa$, NFAT, CREB, HIF-1 $\alpha$, STAT3, and TCF-LEF pathway (Maussang et al., 2009; Slinger et al., 2010; Langemeijer et al., 2012; de Wit et al., 2016). Activation of these transcription factors leads to the activation of cyclin D1 and cyclooxygenase 2 , resulting in the secretion of PGE2, IL-6, and VEGF, inducing enhanced inflammation, proliferation, and angiogenesis. Although US28 ligandindependent signaling plays an important role, liganddependent signaling is also of significance. Scavenging of CCL5 via CCL5-specific antibodies reduces US28enhanced invasiveness of primary glioblastoma cells (Soroceanu et al., 2011). Moreover, CCL5 enhances US28 signaling, resulting in enhanced $\beta$-catenin signaling and phospholipase $\mathrm{C}$ activation (Langemeijer et al., 2012; Heukers et al., 2018). As multiple US28 ligands are expressed at high levels in, for example, glioblastoma, it is reasonable that ligand-dependent US28 signaling plays an important factor in the oncomodulatory role of HCMV (Desbaillets et al., 1994). Via the activation of these oncogenic pathways, US28 expression led to enhanced tumor growth in vivo in different cancer models. In an orthotopic glioblastoma model, US28-expressing U251 glioblastoma tumors showed significant tumor expansion already at day 10 postsurgery, whereas this was only observed at day 40 for control U251 tumors (Heukers et al., 2018). Moreover, infection of U251 and primary glioblastoma cells with HCMV led to an increase in spheroid and neurosphere size, which was not as apparent when cells were infected with an HCMV mutant devoid of US28. Furthermore, in a colitis-tumor model, transgenic mice that expressed US28 in intestinal epithelial cells displayed a higher tumor burden compared with control mice (Bongers et al., 2010). Moreover, coexpression of CCL2 resulted in enhanced tumorigenesis, suggesting a potential direct interaction between CCL2 and US28 signaling in this model. Finally, G protein-dependent US28 signaling does not seem to be solely responsible for enhanced tumor growth. Using a xenograft model, NIH-3T3 cells stably expressing a G protein-uncoupled US28 mutant (US28 R129A/R ${ }^{3.50} \mathrm{~A}$ ) still showed US28enhanced tumor growth, although not to such an extent as NIH-3T3 cells expressing US28 and wild-type receptor (Maussang et al., 2006).

Besides US28, an oncomodulatory role for the other HCMV-encoded GPCR UL33 has also been recently described (van Senten et al., 2019). Similar to US28, UL33 activates multiple signaling pathways, resulting in NFAT-, CREB-, HIF- $1 \alpha-$, STAT3-, and TCFLEF-mediated transcription. Strikingly, UL33 signaling did not activate the NF- $\kappa \mathrm{B}$ pathway, in contrast to US28. Similar to US28, UL33 signaling resulted in enhanced IL-6 secretion in glioblastoma cells and resulted in enhanced three-dimensional tumor spheroid growth. Using an orthotopic glioblastoma model similar to before, UL33 expression in glioblastoma cells also resulted in enhanced tumor growth, albeit with a delayed onset compared with US28. In HCMVinfected glioblastoma cells, differences in spatiotemporal expression of both receptors was observed, making it plausible that the receptors complement each other when rewiring cellular signaling of the infected cells in a cancer setting. Overall, similar to US28 (but less pronounced), the constitutive activity of HCMV-encoded UL33 is able to activate oncogenic pathways and enhance tumor growth.

\section{B. Cardiovascular Diseases}

HCMV infection has also been associated with the development of vascular diseases such as atherosclerosis, which is an underlying cause of acute myocardial infarction (Melnick et al., 1996). Although the specific role of HCMV and vascular diseases is still being debated, HCMV seropositivity has been associated with artery diseases, and HCMV nucleic acids and antigens have been detected in vessels of patients (Melnick et al., 1983; Horváth et al., 2000). Moreover, HCMV is known to infect cell types such as macrophages, smooth muscle cells, and endothelial cells, which play an important role in cardiovascular diseases (Caposio et al., 2011). Over the past years, the Streblow laboratory has shown that US28 signaling mediates migration of these types of cells, which is an important underlying factor in cardiovascular diseases (Streblow et al., 1999, 2003; Melnychuk et al., 2004; Vomaske et al., 2009). Interestingly, ligand-dependent US28 signaling and cellular backgrounds play key roles in cell migration. For example, CCL5 binding to US28 promotes smooth muscle cell migration via coupling of $\mathrm{G} \alpha_{12 / 13}$, resulting in activation of the Srcfocal adhesion kinase signaling pathway. However, CX3CL1 binding to US28 inhibits CCL5-mediated smooth muscle cell migration (Streblow et al., 1999, 2003; Melnychuk et al., 2004; Vomaske et al., 2009). In contrast, CX3CL1 induces US28-mediated macrophage migration in a $\mathrm{G} \alpha_{\mathrm{q}}$-dependent manner, whereas this is inhibited by CCL5 binding to the receptor (Vomaske et al., 2009; Hjortø et al., 2013). Taken together, these results show that HCMV and US28 can result in infiltration of smooth muscle cells in the vessel intima, resulting in narrowing of the vessels, and infiltration of HCMV-infected monocytes and macrophages into atherosclerotic lesions. Finally, HCMV-infected endothelial cells also show an increase of secreted cytokines and growth factors (including IL-6 and VEGF) involved in angiogenesis and wound healing (Dumortier et al., 2008). As US28 signaling induces IL-6 and VEGF secretion, it could play an important role in the enhanced secretion of 
TABLE 2

Overview of US28-targeting and modulating agents

\begin{tabular}{|c|c|c|c|c|c|c|}
\hline Molecule Class & Molecule Name/Scaffold & Mode of Action & $\begin{array}{l}\text { Infection } \\
\text { State }\end{array}$ & $\begin{array}{l}\text { In } \\
\text { Vitro/ } \\
\text { In Vivo }\end{array}$ & Functional Effect & Reference \\
\hline \multirow[t]{4}{*}{$\begin{array}{l}\text { Small } \\
\text { molecule }\end{array}$} & $\begin{array}{l}\text { Piperazinyldibenzothiepins; } \\
\text { cinchonine derivates; cinchonidines } \\
\text { derivates; arylamines; benzamides }\end{array}$ & Antagonists & - & $\begin{array}{l}\text { In } \\
\text { vitro }\end{array}$ & Ligand blocking & Vischer et al. (2014) \\
\hline & $\begin{array}{l}\text { Methiothepin; Octoclothepin; } \\
\text { S-(-)-Iodobenzamide }\end{array}$ & $\begin{array}{l}\text { Antagonist/partial } \\
\text { inverse agonist }\end{array}$ & - & $\begin{array}{l}\text { In } \\
\text { vitro }\end{array}$ & $\begin{array}{l}\text { Ligand blocking and } \\
\text { partial inhibition of US28 } \\
\text { constitutive activity }\end{array}$ & Vischer et al. (2010) \\
\hline & VUF2274 & $\begin{array}{l}\text { Antagonist/full } \\
\text { inverse agonist }\end{array}$ & $\begin{array}{c}\text { Latent } \\
\text { infection }\end{array}$ & $\begin{array}{l}\text { In } \\
\text { vitro }\end{array}$ & $\begin{array}{l}\text { Full reactivation of } \\
\text { latently infected cells } \\
\text { resulting in }\end{array}$ & $\begin{array}{l}\text { Casarosa et al. } \\
(2003 b) ; \text { Krishna } \\
\text { et al. }(2017 a)\end{array}$ \\
\hline & $\begin{array}{c}\text { Derivates of flavonoids; biphenyl } \\
\text { amides; CX3CR1 antagonists; } \\
\text { VUF2274 }\end{array}$ & $\begin{array}{l}\text { Agonist; } \\
\text { antagonist; inverse } \\
\text { agonist }\end{array}$ & - & $\begin{array}{l}\text { In } \\
\text { vitro }\end{array}$ & $\begin{array}{l}\text { Ligand blocking/enhanced } \\
\text { US28 signaling/partial } \\
\text { inhibition of US28 } \\
\text { constitutive activity }\end{array}$ & $\begin{array}{l}\text { Kralj et al. (2011), } \\
\text { (2013), (2014); } \\
\text { Lückmann et al. } \\
\text { (2017); Amărandi } \\
\text { et al. (2018) }\end{array}$ \\
\hline \multirow[t]{3}{*}{ Nanobody } & $\mathrm{US} 28-\mathrm{Nb}$ & Antagonist & $\begin{array}{l}\text { Cancer } \\
\text { setting }\end{array}$ & $\begin{array}{l}\text { In } \\
\text { vitro }\end{array}$ & Ligand blocking & Heukers et al. (2018) \\
\hline & Bivalent US28-Nb & $\begin{array}{l}\text { Antagonist/partial } \\
\text { inverse agonist }\end{array}$ & $\begin{array}{l}\text { Cancer } \\
\text { setting }\end{array}$ & $\begin{array}{l}\text { In } \\
\text { vitro/ } \\
\text { in } \\
\text { vivo }\end{array}$ & $\begin{array}{l}\text { Partial inhibition of } \\
\text { US28-mediated enhanced } \\
\text { glioblastoma tumor } \\
\text { growth }\end{array}$ & Heukers et al. (2018) \\
\hline & VUN100-PS & $\begin{array}{c}\text { Antagonist/ } \\
\text { photosensitizer- } \\
\text { induced cell death }\end{array}$ & $\begin{array}{l}\text { Cancer } \\
\text { setting }\end{array}$ & $\begin{array}{l}\text { In } \\
\text { vitro }\end{array}$ & $\begin{array}{l}\text { Selective killing of US28- } \\
\text { expressing glioblastoma } \\
\text { cells }\end{array}$ & $\begin{array}{l}\text { De Groof et al. } \\
(2019 b)\end{array}$ \\
\hline \multirow[t]{2}{*}{$\begin{array}{l}\text { Toxin-coupled } \\
\text { chemokine }\end{array}$} & F49A-FTP & $\begin{array}{l}\text { Toxin-induced cell } \\
\text { death }\end{array}$ & $\begin{array}{l}\text { Lytic } \\
\text { infection }\end{array}$ & $\begin{array}{l}\text { In } \\
\text { vitro/ } \\
\text { in } \\
\text { vivo }\end{array}$ & $\begin{array}{l}\text { Selective killing of } \\
\text { HCMV-infected cells }\end{array}$ & Spiess et al. (2015b) \\
\hline & & & $\begin{array}{l}\text { Latent } \\
\text { infection }\end{array}$ & $\begin{array}{l}\text { In } \\
\text { vitro }\end{array}$ & & $\begin{array}{l}\text { Krishna et al. } \\
\text { (2017b) }\end{array}$ \\
\hline
\end{tabular}

these factors found in HCMV-infected endothelial cells (Maussang et al., 2009).

\section{Post-transplant Disease}

Viral GPCRs contribute to important in vivo processes such as viral dissemination, latency and reactivation, and immune evasion (described in section $I I$ Viral G Protein-Coupled Receptors in a Viral Setting). During solid organ or hematopoietic stem cell transplantation (HSCT), immunosuppressive regimes combined with inflammation commonly lead to systemic reactivation of herpesviruses (Haidar and Singh, 2017; Hill et al., 2017). HCMV reactivation from latency causes disease depending on the nature of the graft (HSCT, solid organ) and the serostatus of both the donor and recipient, whereas the source of the reactivation may come from either party (Ramanan and Razonable, 2013; Stern et al., 2019). The complex interplay between virus and host during transplantation is not fully dissected, although animal models have already shown that HCMV-encoded GPCRs contribute to posttransplant disease. Deletion of Rat CMV R33 reduced vascular sclerosis and increased time to chronic rejection in a rat model of heart transplantation, and deletion of MCMV M33 reduced cardiac allograft vasculopathy in a mouse model of aortic transplantation (Streblow et al., 2005; Fritz et al., 2018). These animal models continue to be developed, including the generation of a humanized mice model, which may soon lead to further exciting insight about the roles of individual viral genes in post-transplant cytomegalovirus disease (Streblow et al., 2015; Crawford et al., 2020; Gezinir et al., 2020; Holtappels et al., 2020; Shah et al., 2020). However, the species-specific nature of herpesviruses will continue to create challenges in understanding how vGPCRs function in vivo.

Other types of evidence for a role of vGPCRs in transplant-associated disease can also be considered. Observational studies have found US28 antigen or transcript present in renal allografts and in the blood of post-transplant patients (Boomker et al., 2006; Lollinga et al., 2017). As described in section II Viral G Protein-Coupled Receptors in a Viral Setting, US28 and homologs are heavily implicated in in vivo dissemination processes that could be important for the systemic disease often seen post-transplant. US28 also contributes to viral spread in epithelial cells and vascular smooth muscle cells in vitro, which could have particular relevance for solid organ transplantation (Noriega et al., 2014; Lollinga et al., 2017). Finally, US28 plays an important role in the latency of human cytomegalovirus (Humby and O'Connor, 2015; Krishna et al., 2017a; Zhu et al., 2018; Crawford et al., 2019). The latent reservoir of HCMV in hematopoietic stem cells and their myeloid derivatives is believed to be key in the reactivation of HCMV post-HSCT (Stern et al., 2019). At least one mechanism by which US28 contributes to latency is the suppression of major immediate early gene expression in early myeloid lineage cells, a function lost or even reversed in differentiated dendritic cells 
(Krishna et al., 2018; Elder and Sinclair, 2019). Furthermore, US28 influences myelopoiesis and myeloid differentiation (Zhu et al., 2018; Crawford et al., 2019), which could potentially contribute to the well established myelosuppression caused by HCMV in vitro (Rakusan et al., 1989; Sing and Ruscetti, 1990; Maciejewski and St Jeor, 1999; Mason et al., 2012; Hancock et al., 2020) and thus to the defects in engraftment observed in the clinic during HSCT (Sing and Ruscetti, 1995; Stern et al., 2019). As US28 is likely to be an important player in posttransplant events, the targeting of US28 is of great interest as a strategy to reduce the burden of CMV disease in this disease setting.

\section{Viral G Protein-Coupled Receptor-Targeting Modulators and Therapeutics}

Although the studies described above revealed important roles for different viral GPCRs in various pathologies, agents modulating the activity of viral GPCRs have so far only been described for the HCMVencoded US28 (Table 2). These inhibitors include both small molecules and antibody fragments. Based on their mode of action, these can be divided into neutral antagonists (i.e., blocking US28 ligand binding) or inverse agonists (i.e., blocking US28 ligand binding and inhibiting the constitutive activity). In addition, chemokine-derived fusion proteins have been developed for targeted therapy of HCMV-infected cells. Some of these different US28-targeting agents have been used to target HCMV-infected cells in latent infection and in cancer models and will be described more in detail below.

\section{A. Small Molecules}

In the beginning of this century, multiple different chemical scaffolds (benzamides, cinchonine and derivatives, arylamines, and piperazinyldibenzothiepins) were patented for their ability to act as US28 antagonists in in vitro signaling assays (Vischer et al., 2014). Some of these drugs, including methiothepin and octoclothepin, inhibited US28 ligand binding and partially inhibited the constitutive activity of US28 (Vischer et al., 2010).

Besides these scaffolds, other small molecules were also described in literature. One interesting example is VUF2274, which was identified as a full inverse agonist (Casarosa et al., 2003b). VUF2274, derived from a CCR1 antagonist scaffold, inhibited chemokine binding and was the first molecule to inhibit the constitutive activity of US28 with micromolar potency. Moreover, US28 has been described as a coreceptor for HIV-1 entry. VUF2274 could partially inhibit this US28-mediated HIV-1 entry. In later studies, VUF2274 was used to establish the essential role of US28 in the HCMV latency (Krishna et al., 2017a). Treatment of latently infected CD14+ monocytes with VUF2274 resulted in full reactivation of HCMV in these cells. Moreover, VUF2274 treatment drove recognition and killing of the reactivated monocytes by HCMV-specific T cells isolated from HCMV-positive donors.

In more recent years, other groups have generated other small molecules against US28, which are based on either flavonoids, biphenyl amides, CX3CR1 antagonists, or the VUF2274 as scaffold (Kralj et al., 2011, 2013, 2014; Lückmann et al., 2017; Amărandi et al., 2018). This new panel of molecules acted as agonists, antagonists, or inverse agonists depending on the cell type. Although multiple small molecules against US28 have been identified, most of these compounds were unsuitable for a clinical application without further improvements. Some have affinities and potencies in the micromolar range, whereas others were shown to be cytotoxic and/or showed crossreactivity toward other GPCRs, making them poor candidates for in vivo testing and subsequent clinical development. However, the availability of these compounds, in combination with the structural information from the crystal structure of US28 in complex with CX3CL1, provides a strong basis for the development of more and/or improved small molecules against US28 (Burg et al., 2015).

\section{B. Toxin-Coupled Chemokines}

The binding of chemokines to their cognate receptors can be exploited for the targeted delivery of effector molecules. For example, toxins can be redirected to cells of interest via fusion to targeting molecules (Allahyari et al., 2017). Upon binding, the fusion toxin protein (FTP) is internalized, and the toxin is processed and activated within the cell. Because of this mechanism of action, toxin-induced cell death can occur only upon proper uptake and processing of the FTP. Popular examples of toxins used for FTPs include bacterial toxins like Pseudomonas exotoxin A (PE38) and diphtheria toxin and plant toxins like ricin (Allahyari et al., 2017). In most cases, these molecules are targeted via antibody fragments binding to receptors or markers that are (over)expressed on the target cell, classifying them as immunotoxins.

Recently, PE38 was also fused to chemokines to target the toxin to US28-expressing cells (Spiess et al., 2015b, 2017; Krishna et al., 2017b). US28 is known to bind multiple chemokines, and interestingly, CX3CL1 binds US28 with a higher affinity than the native host receptor CX3CR1 (Casarosa et al., 2005). Based on this, the soluble part of CX3CL1 was used as a scaffold to design a mutant with even more enhanced selectivity toward US28 (Spiess et al., 2015b). Fusion of PE38 to this CX3CL1 mutant resulted in killing of lytically infected cells and antiviral activity in infected humanized mice (Spiess et al., 2015b). In follow-up studies, CX3CL1-based FTP was able to specifically kill latently infected cells, suggesting that the HCMV latent 
reservoir could be cleared with the fusion toxin protein (Krishna et al., 2017b).

Despite these promising results, there are some challenges to be taken into account. Serial passage of HCMV resulted in the development of resistance mutants with a truncated US28 (having a premature stop codon in the extracellular loop 3). This results in reduced surface expression of US28, lowering the number of entry points for FTPs (Spiess et al., 2015b). Moreover, FTPs are known to be highly immunogenic, which hampers clinical development because of the risk of developing anti-drug antibodies (Allahyari et al., 2017). Finally, despite a slightly higher selectivity toward US28, the CX3CL1-based fusion toxin protein still binds to CX3CR1. This could lead to off-target effects at higher concentrations in vivo. However, ex vivo treatment, using normothermic perfusion, of HCMV-positive organs prior to transplantation could negate these problems (Vp Ribeiro et al., 2020).

\section{Viral G Protein-Coupled \\ Receptor-Targeting Nanobodies}

As an alternative to the small molecules, more recent research has been focusing on finding GPCR-targeting antibodies and fragments thereof. In particular, nanobodies (antibody fragments derived from the heavy chain-only antibodies of camelids) have gained a lot of interest because of their ability to recognize and stabilize the nonlinear, conformational epitopes typically found of GPCRs (De Groof et al., 2019a; Heukers et al., 2019). These characteristics have been instrumental for the generation of GPCR crystals, thereby allowing the reconstruction of GPCR structures. The first structures of GPCRs stabilized by intracellularly binding nanobodies were reported by Kobilka and Steyaert and colleagues for the $\beta 2$-adrenergic receptor (Rasmussen et al., 2011). We have shown that nanobodies can also specifically bind the extracellular side of GPCRs-namely, CXCR4 and ACKR3 (also known as CXCR7)—and modulate their function in vitro and in vivo (Jähnichen et al., 2010; Maussang et al., 2013). GPCR-targeting nanobodies are interesting modalities to image, stabilize, and modulate GPCRs, as they can be easily formatted and target GPCRs from either the extracellular side or the intracellular side (De Groof et al., 2019a; Heukers et al., 2019).

In 2018, we generated a US28-targeting nanobody (US28-Nb) by immunizing a llama and an alpaca with DNA encoding this GPCR, followed by US28-expressing cells (Heukers et al., 2018). Pharmacological characterization of the US28-Nb showed that the nanobody was able to displace US28 ligands with sub-micromolar affinity. Genetically coupling two of these US28-Nbs through a long flexible glycine-serine linker, generating a bivalent US28- $\mathrm{Nb}$, resulted in a 100 -fold increase in apparent binding affinity and potency (low nanomolar range) through avid binding. Moreover, as previously observed for the CXCR4 and ACKR3 nanobodies, this also resulted in partial inverse agonistic properties. The bivalent US28-Nb was able to inhibit US28 constitutive activity up to $50 \%$. As a consequence, this bivalent molecule was able to impair US28mediated glioblastoma tumor growth both in vitro and in vivo.

In a follow-up study, and to find more potent candidates, new US28-targeting nanobodies were generated through new immunizations and phage panning (De Groof et al., 2019b). One lead nanobody, termed VUN100, bound to a similar epitope on the extracellular domains of US28 as the previous US28-Nb. VUN100 also acted as an antagonist by competing with CCL5 and CX3CL1 for binding to US28, but with a 170-fold increase in potency as compared with the previous nanobody. Having a US28-targeting nanobody with nanomolar affinity enabled us to use this nanobody for targeted therapy approaches. By introducing a C-terminal cysteine to the nanobody, the photosensitizer IRDye700DX was directionally conjugated to VUN100. Treatment of US28expressing glioblastoma cells and subsequent illumination of the nanobody-photosensitizer conjugate with near-infrared light resulted in specific killing of US28-expressing two-dimensional and three-dimensional in vitro cultures.

\section{Concluding Remarks and Future Perspectives}

The relevance of viral GPCRs in the viral life cycle and herpesvirus-associated diseases has become clear over the last decade. However, there are still some unanswered questions that remain to be addressed.

\section{A. Pharmacological Characterization of Viral G Protein-Coupled Receptors}

From a pharmacological point of view, we have been able to elucidate multiple aspects of several of these vGPCRs. However, some of these vGPCRs are still designated as orphan GPCRs. As such, it would be interesting to further explore which potential ligands bind these receptors. To date, only chemokines have been identified as ligands for these vGPCRs. However, it is not unlikely that other classes of ligands can bind to these receptors. It has, for example, been proposed that US28-mediated establishment and maintenance of latency could be driven by an unknown US28 ligand that binds differently to US28 as compared with the known (chemokine) ligands (Krishna et al., 2019). Moreover, nonchemokine ligands, such as macrophage migration inhibitory factor (MIF), have already been shown to bind to human chemokine receptors such as CXCR2 and CXCR4 (Weber et al., 2008; Kraemer et al., 2011; Rajasekaran et al., 2016). Performing (highthroughput) ligand binding screening assays using bioluminescence resonance energy transfer (BRET) or fluorescence resonance energy transfer (FRET) technology 
could unveil novel ligands binding to these vGPCRs, which could lead to more insight into receptor function.

In addition, not much is known about the signaling pathways or the influence on cellular signaling of some of these receptors. In particular, limited information is available on the signaling properties of HCMV-encoded US27 and UL78, HHV-6-encoded U12, and HHV7-encoded U12 and U51. It is unlikely, from an evolutionary point of view, that these herpesviruses contain genes encoding for nonfunctional vGPCRs. As such, further investigation into the signaling properties of the vGPCRs, their ability to form dimers with GPCRs of the host, or scavenging of ligands and thereby influencing cellular signaling would be interesting to pursue. Currently, most studies have focused on G proteins and $G$ protein-mediated signaling. However, GPCRs can also signal in a $G$ protein-independent manner (Gurevich and Gurevich, 2019). This can include signaling via arrestins or $\mathrm{G}$ protein-coupled receptor kinases (GRK). Moreover, GPCRs can interact with proteins via PDZ-binding motifs regulating GPCR signaling and localization (Dunn and Ferguson, 2015). Further investigation of signaling via different G protein-independent signaling pathways through PDZbinding motifs (and associated PDZ domain-containing proteins) or other vGPCR-interacting proteins could provide new insight into the signaling properties of one or more vGPCRs. Moreover, it would be interesting to investigate the interactome of vGPCRs in different cell types, as it has become clear that the cellular context is an important factor when studying vGPCR signaling. Finally, the various studies that investigated vGPCR signaling focused on vGPCRs in isolation. An important step is to monitor the effects of vGPCR signaling on cellular signaling in a viral setting, since the influence of other vGPCRs or other viral proteins should be taken into account.

\section{B. In Vivo Model Systems}

To date, some of the roles of vGPCRs in the viral life cycle and disease settings have been elucidated via in vitro experiments. However, translating this to a more relevant in vivo setting remains challenging because of host tropism. Further research into novel transgenic herpesvirus strains or novel in vivo models could prove to be useful in gaining more insight into herpesviruses and validation of potential antivirals. To this end, humanized mouse models, which have been described above, seem to be a very interesting, although technically challenging, approach that could bridge the gap between the current in vitro experiments and clinical research.

\section{Therapeutic Targeting of Viral G \\ Protein-Coupled Receptors}

Despite the limited information on the role of vGPCRs in vivo, it has become clear that these receptors could serve as a promising drug target in several disease settings. To date, this has resulted in the identification of several classes of US28-targeting molecules. For the other vGPCRs, no molecules against these receptors have been reported to our knowledge. However, several studies have shown that multiple chemokines have agonistic or inverse agonistic properties on ORF74 signaling (Geras-Raaka et al., 1998; Rosenkilde et al., 1999). Moreover, one of these studies shows that $\mathrm{Zn}^{2+}$ ions have inverse agonistic effects on an ORF74 mutant receptor in which histidine residues have been introduced, suggesting that nonpeptidergic inverse agonists could be designed (Rosenkilde et al., 1999). Overall, these studies show that ORF74-targeting molecules could be designed. Moreover, other vGPCR-targeting molecules would be valuable tools and are potential therapeutics to identify and develop.

1. US28-Targeting Therapeutics. To date, several small molecules targeting US28 have been reported. However, selectivity, potency, or toxicity of the existing compounds needs to be improved before these compounds could proceed further into clinical studies. As such, optimizing the current compounds or investigating novel small-molecule scaffolds could result in finding more favorable US28-targeting small molecules. In the last couple of years, the Garcia group has gained notable insight in structural features and conformations of US28, which could provide essential information for the development of small molecules with improved affinities (Burg et al., 2015; Miles et al., 2018).

The CX3CL1-based fusion toxin protein has also shown great promise in clearing the HCMV latent pool via targeting of US28. Normothermic perfusion of HCMV-positive organs such as kidneys or lungs with the CX3CL1-based fusion toxin protein could prove to be one of the ways to clear HCMV-infected cells from rejected organs and reduce the waiting list for organ transplantations. One major problem moving forward could be the limited selectivity toward US28, since the CX3CL1-based fusion toxin protein still binds, albeit with low affinity, to the CX3CR1 receptor. This could be resolved by looking into new CX3CL1 mutants that show enhanced selectivity toward US28. Another option would be to conjugate these toxic groups to the US28targeting nanobodies, which do not show any binding toward CX3CR1.

The functionalization of the US28-targeting nanobodies (using photosensitizers) has already shown its potential. However, the potency of this type of therapy needs to be validated in a viral and potentially in vivo setting. Recently, a glioblastoma mouse model using MCMV was used to investigate the role of CMV and glioblastoma (Krenzlin et al., 2019). Potentially, a chimeric MCMV strain in which M33 is replaced by US28 could be used in this setup to validate the potential of US28-targeted photodynamic therapy to clear glioblastoma cells (Farrell et al., 2018). However, it is important 
to note that other functional groups could be conjugated to such nanobodies instead. Some well known examples of cytotoxic domains used in targeted therapies are radioactive isotopes and toxins (De Groof et al., 2019a). In addition, US28 nanobodies could be used to redirect cytotoxic immune cells via coupling to T-cell or natural killer cell engagers or a chimeric antigen receptor $\mathrm{T}$ cells (CAR-T) approach, whereby $\mathrm{T}$ cells are engineered to express the US28 nanobodies as part of the chimeric antigen receptors and are activated upon binding of US28-expressing cells (Rozan et al., 2013; Dong et al., 2016; Li et al., 2018). Moreover, functionalized US28 nanobodies not only could be used in targeted cancer therapy but also could be of great interest in a cardiovascular or post-transplant disease setting.

Finally, bivalent formats of the US28-targeting nanobodies have inverse agonistic properties, which could be interesting for the clearance of the HCMV latent pool. Inhibiting the US28 constitutive activity using the full inverse agonist VUF2274 has already shown to fully reactivate latently infected cells. However, it would be interesting to investigate the effect of partial inverse agonistic US28-targeting nanobodies on HCMV reactivation.

\section{Other Viral G Protein-Coupled Receptors as Drug} Targets. Although research has mostly been focusing on finding US28-targeting therapeutics, targeting of other vGPCRs in specific disease settings would be an interesting approach. As such, modulators (small molecules, peptides, nanobodies, antibodies) targeting these vGPCRs are attractive, although none have been reported yet. Identification of modulators against the other vGPCRs would be important tools to further investigate the roles of these receptors in specific disease settings.

Besides modulating the receptor activity, these vGPCRs could also be used for targeted (cancer) therapy using similar approaches used for US28-targeted therapies. As such, finding (functionalized) nanobodies or toxin-coupled chemokine mutants targeting these vGPCRs could be envisioned. For instance, ORF74, BILF1, and UL33 are expressed on different types of cancer cells, making them appealing for targeted cancer therapy. Besides cancer treatment, other vGPCRs could also be interesting for the clearance of the latent pool via targeted therapy. In the case of HCMV, UL78 and UL33 are also potentially expressed in latently infected cells and could be useful additional targets. Moreover, BILF1 and ORF74 are also expressed during latency, but only at low levels. As expression levels are an important parameter for successful targeted therapy, it remains to be seen whether these expression levels are adequate.

Taken together, vGPCRs can be considered as attractive drug targets, as they redirect cellular signaling and significantly contribute and/or exacerbate proliferative, cardiovascular, and post-transplant diseases. Moreover, they play a prominent role in latency and immune evasion, thus escaping immune surveillance vital for the persistence of herpesviruses. Hence, modulators targeting vGPCRs are essential to further delineate their impact on disease progression and can be regarded as promising therapeutics for antiviral, cancer, and/or cardiovascular disease treatment.

\section{Authorship Contributions}

Wrote or contributed to the writing of the manuscript: De Groof, Elder, Siderius, Heukers, Sinclair, Smit.

\section{References}

Alcendor DJ, Zong J, Dolan A, Gatherer D, Davison AJ, and Hayward GS (2009) Patterns of divergence in the vCXCL and vGPCR gene clusters in primate cytomegalovirus genomes. Virology 395:21-32.

Allahyari H, Heidari S, Ghamgosha M, Saffarian P, and Amani J (2017) Immunotoxin: a new tool for cancer therapy. Tumour Biol 39:1010428317692226.

Amărandi RM, Lückmann M, Melynis M, Jakobsen MH, Fallah Z, Spiess K, Hjortø GM, Pui A, Frimurer TM, and Rosenkilde MM (2018) Ligand-selective small molecule modulators of the constitutively active vGPCR US28. Eur J Med Chem 155:244-254

Arfelt KN, Fares S, and Rosenkilde MM (2015) EBV, the human host, and the 7TM receptors: defense or offense? Prog Mol Biol Transl Sci 129:395-427.

Arnolds KL, Lares AP, and Spencer JV (2013) The US27 gene product of human cytomegalovirus enhances signaling of host chemokine receptor CXCR4. Virology 439:122-131.

Arvanitakis L, Geras-Raaka E, Varma A, Gershengorn MC, and Cesarman E (1997) Human herpesvirus KSHV encodes a constitutively active G-protein-coupled receptor linked to cell proliferation. Nature 385:347-350.

Aslam Y, Williamson J, Romashova V, Elder E, Krishna B, Wills M, Lehner P, Sinclair J, and Poole E (2019) Human cytomegalovirus upregulates expression of HCLS1 resulting in increased cell motility and transendothelial migration during latency. iScience 20:60-72.

Avdic S, McSharry BP, Steain M, Poole E, Sinclair J, Abendroth A, and Slobedman B (2016) Human cytomegalovirus-encoded human Interleukin-10 (IL-10) homolog amplifies its immunomodulatory potential by upregulating human IL-10 in monocytes. J Virol 90:3819-3827.

Bais C, Van Geelen A, Eroles P, Mutlu A, Chiozzini C, Dias S, Silverstein RL, Rafii S, and Mesri EA (2003) Kaposi's sarcoma associated herpesvirus G protein-coupled receptor immortalizes human endothelial cells by activation of the VEGF receptor2/KDR. Cancer Cell 3:131-143.

Bakker RA, Casarosa P, Timmerman H, Smit MJ, and Leurs R (2004) Constitutively active $\mathrm{Gq} / 11$-coupled receptors enable signaling by co-expressed $\mathrm{G}(\mathrm{i} / \mathrm{o})$-coupled receptors. J Biol Chem 279:5152-5161.

Baryawno N, Rahbar A, Wolmer-Solberg N, Taher C, Odeberg J, Darabi A, Khan Z, Sveinbjörnsson B, FuskevÅg OM, Segerström L, et al. (2011) Detection of human cytomegalovirus in medulloblastomas reveals a potential therapeutic target. J Clin Invest 121:4043-4055.

Beisser PS, Verzijl D, Gruijthuijsen YK, Beuken E, Smit MJ, Leurs R, Bruggeman CA, and Vink C (2005) The Epstein-Barr virus BILF1 gene encodes a G proteincoupled receptor that inhibits phosphorylation of RNA-dependent protein kinase. $J$ Virol 79:441-449.

Beisser PS, Vink C, Van Dam JG, Grauls G, Vanherle SJ, and Bruggeman CA (1998) The R33 G protein-coupled receptor gene of rat cytomegalovirus plays an essential role in the pathogenesis of viral infection. $J$ Virol 72:2352-2363.

Billstrom MA, Lehman LA, and Scott Worthen G (1999) Depletion of extracellular RANTES during human cytomegalovirus infection of endothelial cells. Am J Respir Cell Mol Biol 21:163-167.

Bleul CC, Wu L, Hoxie JA, Springer TA, and Mackay CR (1997) The HIV coreceptors CXCR4 and CCR5 are differentially expressed and regulated on human T lymphocytes. Proc Natl Acad Sci USA 94:1925-1930.

Bodaghi B, Jones TR, Zipeto D, Vita C, Sun L, Laurent L, Arenzana-Seisdedos F, Virelizier JL, and Michelson S (1998) Chemokine sequestration by viral chemoreceptors as a novel viral escape strategy: withdrawal of chemokines from the environment of cytomegalovirus-infected cells. J Exp Med 188:855-866.

Boeck JM, Stowell GA, O'Connor CM, and Spencer JV (2018) The human cytomegalovirus US27 gene product constitutively activates antioxidant response elementmediated transcription through $\mathrm{G}_{\beta} \gamma$, phosphoinositide 3-kinase, and nuclear respiratory factor 1. J Virol 92:e0644-e00718.

Bongers G, Maussang D, Muniz LR, Noriega VM, Fraile-Ramos A, Barker N, Marchesi F, Thirunarayanan N, Vischer HF, Qin L, et al. (2010) The cytomegalovirusencoded chemokine receptor US28 promotes intestinal neoplasia in transgenic mice. J Clin Invest 120:3969-3978.

Boomker JM, Verschuuren EA, Brinker MG, de Leij LF, The TH, and Harmsen MC (2006) Kinetics of US28 gene expression during active human cytomegalovirus infection in lung-transplant recipients. J Infect Dis 193:1552-1556.

Bottero V, Sharma-Walia N, Kerur N, Paul AG, Sadagopan S, Cannon M, and Chandran B (2009) Kaposi sarcoma-associated herpes virus (KSHV) G protein coupled receptor (vGPCR) activates the ORF50 lytic switch promoter: a potential positive feedback loop for sustained ORF50 gene expression. Virology 392:34-51.

Burg JS, Ingram JR, Venkatakrishnan AJ, Jude KM, Dukkipati A, Feinberg EN, Angelini A, Waghray D, Dror RO, Ploegh HL, et al. (2015) Structural biology. Structural basis for chemokine recognition and activation of a viral G proteincoupled receptor. Science 347:1113-1117. 
Cai ZZ, Xu JG, Zhou YH, Zheng JH, Lin KZ, Zheng SZ, Ye MS, He Y, Liu CB, and Xue ZX (2016) Human cytomegalovirus-encoded US28 may act as a tumor promoter in colorectal cancer. World J Gastroenterol 22:2789-2798.

Caposio P, Orloff SL, and Streblow DN (2011) The role of cytomegalovirus in angiogenesis. Virus Res 157:204-211.

Cardin RD, Schaefer GC, Allen JR, Davis-Poynter NJ, and Farrell HE (2009) The M33 chemokine receptor homolog of murine cytomegalovirus exhibits a differential tissue-specific role during in vivo replication and latency. J Virol 83:7590-7601.

Casarosa P, Gruijthuijsen YK, Michel D, Beisser PS, Holl J, Fitzsimons CP, Verzijl D, Bruggeman CA, Mertens T, Leurs R, et al. (2003a) Constitutive signaling of the human cytomegalovirus-encoded receptor UL33 differs from that of its rat cytomegalovirus homolog R33 by promiscuous activation of $\mathrm{G}$ proteins of the Gq, Gi, and Gs classes. J Biol Chem 278:50010-50023.

Casarosa P, Menge WM, Minisini R, Otto C, van Heteren J, Jongejan A, Timmerman H, Moepps B, Kirchhoff F, Mertens T, et al. (2003b) Identification of the first nonpeptidergic inverse agonist for a constitutively active viral-encoded $\mathrm{G}$ proteincoupled receptor. J Biol Chem 278:5172-5178.

Casarosa P, Waldhoer M, LiWang PJ, Vischer HF, Kledal T, Timmerman H, Schwartz TW, Smit MJ, and Leurs R (2005) CC and CX3C chemokines differentially interact with the $\mathrm{N}$ terminus of the human cytomegalovirus-encoded US28 receptor. J Biol Chem 280:3275-3285.

Case R, Sharp E, Benned-Jensen T, Rosenkilde MM, Davis-Poynter N, and Farrell HE (2008) Functional analysis of the murine cytomegalovirus chemokine receptor homologue M33: ablation of constitutive signaling is associated with an attenuated phenotype in vivo. $J$ Virol 82:1884-1898.

Casper C and Wald A (2007) The use of antiviral drugs in the prevention and treatment of Kaposi sarcoma, multicentric Castleman disease and primary effusion lymphoma. Curr Top Microbiol Immunol 312:289-307.

Catusse J, Spinks J, Mattick C, Dyer A, Laing K, Fitzsimons C, Smit MJ, and Gompels UA (2008) Immunomodulation by herpesvirus U51A chemokine receptor via CCL5 and FOG-2 down-regulation plus XCR1 and CCR7 mimicry in human leukocytes. Eur J Immunol 38:763-777.

Cesarman E (2014) Gammaherpesviruses and lymphoproliferative disorders. Annu Rev Pathol 9:349-372.

Cesarman E, Nador RG, Bai F, Bohenzky RA, Russo JJ, Moore PS, Chang Y, and Knowles DM (1996) Kaposi's sarcoma-associated herpesvirus contains G protein-coupled receptor and cyclin D homologs which are expressed in Kaposi's sarcoma and malignant lymphoma. $J$ Virol 70:8218-8223.

Chabre M, Deterre P, and Antonny B (2009) The apparent cooperativity of some GPCRs does not necessarily imply dimerization. Trends Pharmacol Sci 30: 182-187.

Chambers J, Angulo A, Amaratunga D, Guo H, Jiang Y, Wan JS, Bittner A, Frueh K, Jackson MR, Peterson PA, et al. (1999) DNA microarrays of the complex human cytomegalovirus genome: profiling kinetic class with drug sensitivity of viral gene expression. J Virol 73:5757-5766.

Chang Y, Cesarman E, Pessin MS, Lee F, Culpepper J, Knowles DM, and Moore PS (1994) Identification of herpesvirus-like DNA sequences in AIDS-associated Kaposi's sarcoma. Science 266:1865-1869.

Chen J, Ye F, Xie J, Kuhne K, and Gao SJ (2009) Genome-wide identification of binding sites for Kaposi's sarcoma-associated herpesvirus lytic switch protein RTA. Virology 386:290-302.

Chen YB, Rahemtullah A, and Hochberg E (2007) Primary effusion lymphoma. Oncologist 12:569-576.

Cheng S, Caviness K, Buehler J, Smithey M, Nikolich-Žugich J, and Goodrum F (2017) Transcriptome-wide characterization of human cytomegalovirus in natural infection and experimental latency. Proc Natl Acad Sci USA 114:E10586-E10595.

Chiou CJ, Poole LJ, Kim PS, Ciufo DM, Cannon JS, ap Rhys CM, Alcendor DJ, Zong JC, Ambinder RF, and Hayward GS (2002) Patterns of gene expression and a transactivation function exhibited by the vGCR (ORF74) chemokine receptor protein of Kaposi's sarcoma-associated herpesvirus. J Virol 76:3421-3439.

Clement M and Humphreys IR (2019) Cytokine-mediated induction and regulation of tissue damage during cytomegalovirus infection. Front Immunol 10:78.

Cobbs CS, Harkins L, Samanta M, Gillespie GY, Bharara S, King PH, Nabors LB, Cobbs CG, and Britt WJ (2002) Human cytomegalovirus infection and expression in human malignant glioma. Cancer Res 62:3347-3350.

Cobbs CS, Soroceanu L, Denham S, Zhang W, and Kraus MH (2008) Modulation of oncogenic phenotype in human glioma cells by cytomegalovirus IE1-mediated mitogenicity. Cancer Res 68:724-730.

Crawford LB, Caposio P, Kreklywich C, Pham AH, Hancock MH, Jones TA, Smith PP, Yurochko AD, Nelson JA, and Streblow DN (2019) Human cytomegalovirus US28 ligand binding activity is required for latency in $\mathrm{CD}^{+} 4^{+}$hematopoietic progenitor cells and humanized NSG mice. MBio 10:e01889-e01919.

Crawford LB, Tempel R, Streblow DN, Yurochko AD, Goodrum FD, Nelson JA, and Caposio P (2020) Human cytomegalovirus infection suppresses CD34 ${ }^{+}$progenitor cell engraftment in humanized mice. Microorganisms 8:525.

Danzig JB, Brandt LJ, Reinus JF, and Klein RS (1991) Gastrointestinal malignancy in patients with AIDS. Am J Gastroenterol 86:715-718.

Davis-Poynter NJ, Lynch DM, Vally H, Shellam GR, Rawlinson WD, Barrell BG, and Farrell HE (1997) Identification and characterization of a $\mathrm{G}$ protein-coupled receptor homolog encoded by murine cytomegalovirus. $J$ Virol 71:1521-1529.

De Groof TWM, Bobkov V, Heukers R, and Smit MJ (2019a) Nanobodies: new avenues for imaging, stabilizing and modulating GPCRs. Mol Cell Endocrinol 484: $15-24$

De Groof TWM, Mashayekhi V, Fan TS, Bergkamp ND, Sastre Toraño J, van Senten JR, Heukers R, Smit MJ, and Oliveira S (2019b) Nanobody-targeted photodynamic therapy selectively kills viral GPCR-expressing glioblastoma cells. Mol Pharm 16 $3145-3156$.

de Munnik SM, Smit MJ, Leurs R, and Vischer HF (2015) Modulation of cellular signaling by herpesvirus-encoded G protein-coupled receptors. Front Pharmacol 6:40. de Wit RH, Mujić-Delić A, van Senten JR, Fraile-Ramos A, Siderius M, and Smit MJ (2016) Human cytomegalovirus encoded chemokine receptor US28 activates the HIF-1 $\alpha /$ PKM2 axis in glioblastoma cells. Oncotarget 7:67966-67985.

Desbaillets I, Tada M, de Tribolet N, Diserens AC, Hamou MF, and Van Meir EG (1994) Human astrocytomas and glioblastomas express monocyte chemoattractant protein-1 (MCP-1) in vivo and in vitro. Int J Cancer 58:240-247.

Dominguez G, Dambaugh TR, Stamey FR, Dewhurst S, Inoue N, and Pellett PE (1999) Human herpesvirus 6B genome sequence: coding content and comparison with human herpesvirus 6A. J Virol 73:8040-8052.

Dong B, Zhou C, He P, Li J, Chen S, Miao J, Li Q, and Wang Z (2016) A novel bispecific antibody, BiSS, with potent anti-cancer activities. Cancer Biol Ther 17: 364-370.

Dorsam RT and Gutkind JS (2007) G-protein-coupled receptors and cancer. Nat Rev Cancer 7:79-94.

Droese J, Mokros T, Hermosilla R, Schülein R, Lipp M, Höpken UE, and Rehm A (2004) HCMV-encoded chemokine receptor US28 employs multiple routes for internalization. Biochem Biophys Res Commun 322:42-49.

Dumortier J, Streblow DN, Moses AV, Jacobs JM, Kreklywich CN, Camp D, Smith RD, Orloff SL, and Nelson JA (2008) Human cytomegalovirus secretome contains factors that induce angiogenesis and wound healing. J Virol 82:6524-6535.

Dunn HA and Ferguson SS (2015) PDZ protein regulation of G protein-coupled receptor trafficking and signaling pathways. Mol Pharmacol 88:624-639.

Dziurzynski K, Chang SM, Heimberger AB, Kalejta RF, McGregor Dallas SR, Smit M, Soroceanu L, and Cobbs CS; HCMV and Gliomas Symposium (2012) Consensus on the role of human cytomegalovirus in glioblastoma. Neuro-oncol 14:246-255.

Dziurzynski K, Wei J, Qiao W, Hatiboglu MA, Kong LY, Wu A, Wang Y, Cahill D, Levine N, Prabhu S, et al. (2011) Glioma-associated cytomegalovirus mediates subversion of the monocyte lineage to a tumor propagating phenotype. Clin Cancer Res 17:4642-4649.

El-Asmar L, Springael JY, Ballet S, Andrieu EU, Vassart G, and Parmentier M (2005) Evidence for negative binding cooperativity within CCR5-CCR2b heterodimers. Mol Pharmacol 67:460-469.

Elder E, Krishna B, Williamson J, Aslam Y, Farahi N, Wood A, Romashova V, Roche K, Murphy E, Chilvers E, et al. (2019) Monocytes latently infected with human cytomegalovirus evade neutrophil killing. iScience 12:13-26.

Elder E and Sinclair J (2019) HCMV latency: what regulates the regulators? Med Microbiol Immunol (Berl) 208:431-438.

Fares S, Spiess K, Olesen ETB, Zuo J, Jackson S, Kledal TN, Wills MR, and Rosenkilde MM (2019) Distinct roles of extracellular domains in the epsteinbarr virus-encoded BILF1 receptor for signaling and major histocompatibility complex class I downregulation. MBio 10:e01707-e01718.

Farrell HE, Abraham AM, Cardin RD, Sparre-Ulrich AH, Rosenkilde MM, Spiess K, Jensen TH, Kledal TN, and Davis-Poynter N (2011) Partial functional complementation between human and mouse cytomegalovirus chemokine receptor homologues. $J$ Virol 85:6091-6095

Farrell HE, Bruce K, Ma J, Davis-Poynter N, and Stevenson PG (2018) Human cytomegalovirus US28 allows dendritic cell exit from lymph nodes. J Gen Virol 99: 1509-1514.

Feng H, Sun Z, Farzan MR, and Feng P (2010) Sulfotyrosines of the Kaposi's sarcoma-associated herpesvirus $\mathrm{G}$ protein-coupled receptor promote tumorigenesis through autocrine activation. $J$ Virol 84:3351-3361.

Fiallos E, Judkins J, Matlaf L, Prichard M, Dittmer D, Cobbs C, and Soroceanu L (2014) Human cytomegalovirus gene expression in long-term infected glioma stem cells. PLoS One 9:e116178.

Fitzsimons CP, Gompels UA, Verzijl D, Vischer HF, Mattick C, Leurs R, and Smit MJ (2006) Chemokine-directed trafficking of receptor stimulus to different $\mathrm{g}$ proteins: selective inducible and constitutive signaling by human herpesvirus 6-encoded chemokine receptor U51. Mol Pharmacol 69:888-898.

Fornara O, Bartek J Jr, Rahbar A, Odeberg J, Khan Z, Peredo I, Hamerlik P, Bartek J, Stragliotto G, Landázuri N, et al. (2016) Cytomegalovirus infection induces a stem cell phenotype in human primary glioblastoma cells: prognostic significance and biological impact. Cell Death Differ 23:261-269.

Fortunato EA and Spector DH (1998) p53 and RPA are sequestered in viral replication centers in the nuclei of cells infected with human cytomegalovirus. $J$ Virol 72:2033-2039.

Fortunato EA and Spector DH (2003) Viral induction of site-specific chromosome damage. Rev Med Virol 13:21-37.

Fraile-Ramos A, Kledal TN, Pelchen-Matthews A, Bowers K, Schwartz TW, and Marsh M (2001) The human cytomegalovirus US28 protein is located in endocytic vesicles and undergoes constitutive endocytosis and recycling. Mol Biol Cell 12:1737-1749.

Frank T, Niemann I, Reichel A, and Stamminger T (2019) Emerging roles of cytomegalovirus-encoded $\mathrm{G}$ protein-coupled receptors during lytic and latent infection. Med Microbiol Immunol (Berl) 208:447-456.

Frank T, Reichel A, Larsen O, Stilp AC, Rosenkilde MM, Stamminger T, Ozawa T, and Tschammer N (2016) Attenuation of chemokine receptor function and surface expression as an immunomodulatory strategy employed by human cytomegalovirus is linked to vGPCR US28. Cell Commun Signal 14:31.

Fritz N, Stamminger T, Gocht A, Ramsperger-Gleixner M, Ensminger SM, Weyand M, and Heim C (2018) Deletion of the M33 receptor gene in murine cytomegalovirus reduces levels of cardiac allograft vasculopathy in a murine aortic transplant model. Transplantation 102:S293.

Fukayama M (2010) Epstein-Barr virus and gastric carcinoma. Pathol Int 60 $337-350$.

Gao JL and Murphy PM (1994) Human cytomegalovirus open reading frame US28 encodes a functional beta chemokine receptor. J Biol Chem 269:28539-28542.

Garay SM, Belenko M, Fazzini E, and Schinella R (1987) Pulmonary manifestations of Kaposi's sarcoma. Chest 91:39-43.

Geras-Raaka E, Varma A, Clark-Lewis I, and Gershengorn MC (1998) Kaposi's sarcoma-associated herpesvirus (KSHV) chemokine vMIP-II and human SDF- 
1alpha inhibit signaling by KSHV G protein-coupled receptor. Biochem Biophys Res Commun 253:725-727.

Gershengorn MC, Geras-Raaka E, Varma A, and Clark-Lewis I (1998) Chemokines activate Kaposi's sarcoma-associated herpesvirus G protein-coupled receptor in mammalian cells in culture. $J$ Clin Invest 102:1469-1472.

Gezinir E, Podlech J, Gergely KM, Becker S, Reddehase MJ, and Lemmermann NAW (2020) Enhancement of antigen presentation by deletion of viral immune evasion genes prevents lethal cytomegalovirus disease in minor histocompatibility antigenmismatched hematopoietic cell transplantation. Front Cell Infect Microbiol 10:279.

Gregory CD, Rowe M, and Rickinson AB (1990) Different Epstein-Barr virus-B cell interactions in phenotypically distinct clones of a Burkitt's lymphoma cell line. $J$ Gen Virol 71:1481-1495.

Griffin BD, Gram AM, Mulder A, Van Leeuwen D, Claas FH, Wang F, Ressing ME, and Wiertz E (2013) EBV BILF1 evolved to downregulate cell surface display of a wide range of HLA class I molecules through their cytoplasmic tail. J Immunol 190:1672-1684.

Guo HG, Sadowska M, Reid W, Tschachler E, Hayward G, and Reitz M (2003) Kaposi's sarcoma-like tumors in a human herpesvirus 8 ORF74 transgenic mouse. $J$ Virol 77:2631-2639.

Guo Q, Gao J, Cheng L, Yang X, Li F, and Jiang G (2020) The Epstein-Barr virusencoded G protein-coupled receptor BILF1 upregulates ICAM-1 through a mechanism involving the NF-қB pathway. Biosci Biotechnol Biochem 84:1810-1819.

Gurevich VV and Gurevich EV (2019) GPCR signaling regulation: the role of GRKs and arrestins. Front Pharmacol 10:125.

Haidar G and Singh N (2017) Viral infections in solid organ transplant recipients: novel updates and a review of the classics. Curr Opin Infect Dis 30:579-588.

Hancock MH, Crawford LB, Pham AH, Mitchell J, Struthers HM, Yurochko AD, Caposio P, and Nelson JA (2020) Human cytomegalovirus miRNAs regulate TGF- $\beta$ to mediate myelosuppression while maintaining viral latency in CD34 ${ }^{+}$hematopoietic progenitor cells. Cell Host Microbe 27:104-114.e4.

Harkins L, Volk AL, Samanta M, Mikolaenko I, Britt WJ, Bland KI, and Cobbs CS (2002) Specific localisation of human cytomegalovirus nucleic acids and proteins in human colorectal cancer. Lancet 360:1557-1563.

Hauser AS, Attwood MM, Rask-Andersen M, Schiöth HB, and Gloriam DE (2017) Trends in GPCR drug discovery: new agents, targets and indications. Nat Rev Drug Discov 16:829-842

Heukers R, De Groof TWM, and Smit MJ (2019) Nanobodies detecting and modulating GPCRs outside in and inside out. Curr Opin Cell Biol 57:115-122.

Heukers R, Fan TS, de Wit RH, van Senten JR, De Groof TWM, Bebelman MP, Lagerweij T, Vieira J, de Munnik SM, Smits-de Vries L, et al. (2018) The constitutive activity of the virally encoded chemokine receptor US28 accelerates glioblastoma growth. Oncogene 37:4110-4121.

Hill JA, Mayer BT, Xie H, Leisenring WM, Huang ML, Stevens-Ayers T, Milano F, Delaney C, Sorror ML, Sandmaier BM, et al. (2017) The cumulative burden of double-stranded DNA virus detection after allogeneic HCT is associated with increased mortality. Blood 129:2316-2325.

Hjortø GM, Kiilerich-Pedersen K, Selmeczi D, Kledal TN, and Larsen NB (2013) Human cytomegalovirus chemokine receptor US28 induces migration of cells on a CX3CL1-presenting surface. J Gen Virol 94:1111-1120.

Holst PJ, Rosenkilde MM, Manfra D, Chen SC, Wiekowski MT, Holst B, Cifire F, Lipp M, Schwartz TW, and Lira SA (2001) Tumorigenesis induced by the HHV8encoded chemokine receptor requires ligand modulation of high constitutive activity. J Clin Invest 108:1789-1796.

Holtappels R, Schader SI, Oettel O, Podlech J, Seckert CK, Reddehase MJ, and Lemmermann NAW (2020) Insufficient antigen presentation due to viral immune evasion explains lethal cytomegalovirus organ disease after allogeneic hematopoietic cell transplantation. Front Cell Infect Microbiol 10:157.

Horváth R, Cerný J, Benedík J Jr, Hökl J, Jelínková I, and Benedík J (2000) The possible role of human cytomegalovirus (HCMV) in the origin of atherosclerosis $J$ Clin Virol 16:17-24.

Humby MS and O'Connor CM (2015) Human cytomegalovirus US28 is important for latent infection of hematopoietic progenitor cells. J Virol 90:2959-2970.

Isegawa Y, Ping Z, Nakano K, Sugimoto N, and Yamanishi K (1998) Human herpesvirus 6 open reading frame U12 encodes a functional beta-chemokine receptor. $J$ Virol 72:6104-6112.

Jähnichen S, Blanchetot C, Maussang D, Gonzalez-Pajuelo M, Chow KY, Bosch L, De Vrieze S, Serruys B, Ulrichts H, Vandevelde W, et al. (2010) CXCR4 nanobodies (VHH-based single variable domains) potently inhibit chemotaxis and HIV-1 replication and mobilize stem cells. Proc Natl Acad Sci USA 107: $20565-20570$

Jha HC, Banerjee S, and Robertson ES (2016) The role of gammaherpesviruses in cancer pathogenesis. Pathogens 5:18

Kaptein SJF, Beisser PS, Gruijthuijsen YK, Savelkouls KGM, van Cleef KWR Beuken E, Grauls GELM, Bruggeman CA, and Vink C (2003) The rat cytomegalovirus R78 G protein-coupled receptor gene is required for production of infectious virus in the spleen. J Gen Virol 84:2517-2530.

Kledal TN, Rosenkilde MM, Coulin F, Simmons G, Johnsen AH, Alouani S, Power CA, Lüttichau HR, Gerstoft J, Clapham PR, et al. (1997) A broad-spectrum chemokine antagonist encoded by Kaposi's sarcoma-associated herpesvirus. Science 277:1656-1659.

Kledal TN, Rosenkilde MM, and Schwartz TW (1998) Selective recognition of the membrane-bound CX3C chemokine, fractalkine, by the human cytomegalovirusencoded broad-spectrum receptor US28. FEBS Lett 441:209-214.

Kobilka B (2013) The structural basis of G-protein-coupled receptor signaling (Nobel Lecture). Angew Chem Int Ed Engl 52:6380-6388.

Kraemer S, Lue H, Zernecke A, Kapurniotu A, Andreetto E, Frank R, Lennartz B, Weber C, and Bernhagen J (2011) MIF-chemokine receptor interactions in atherogenesis are dependent on an $\mathrm{N}$-loop-based 2 -site binding mechanism. FASEB $J$ 25:894-906.
Kralj A, Kurt E, Tschammer N, and Heinrich MR (2014) Synthesis and biological evaluation of biphenyl amides that modulate the US28 receptor. ChemMedChem $\mathbf{9}$ : 151-168.

Kralj A, Nguyen MT, Tschammer N, Ocampo N, Gesiotto Q, Heinrich MR, and Phanstiel O 4th (2013) Development of flavonoid-based inverse agonists of the key signaling receptor US28 of human cytomegalovirus. J Med Chem 56: 5019-5032.

Kralj A, Wetzel A, Mahmoudian S, Stamminger T, Tschammer N, and Heinrich MR (2011) Identification of novel allosteric modulators for the G-protein coupled US28 receptor of human cytomegalovirus. Bioorg Med Chem Lett 21:5446-5450.

Krenzlin H, Behera P, Lorenz V, Passaro C, Zdioruk M, Nowicki MO, Grauwet K, Zhang H, Skubal M, Ito H, et al. (2019) Cytomegalovirus promotes murine glioblastoma growth via pericyte recruitment and angiogenesis. J Clin Invest 129: 1671-1683

Krishna BA, Humby MS, Miller WE, and O'Connor CM (2019) Human cytomegalovirus $\mathrm{G}$ protein-coupled receptor US28 promotes latency by attenuating c-fos. Proc Natl Acad Sci USA 116:1755-1764.

Krishna BA, Miller WE, and O'Connor CM (2018) US28: HCMV's Swiss army knife. Viruses 10:445.

Krishna BA, Poole EL, Jackson SE, Smit MJ, Wills MR, and Sinclair JH (2017a) Latency-associated expression of human cytomegalovirus US28 attenuates cell signaling pathways to maintain latent infection. MBio 8:e01754-e01817.

Krishna BA, Spiess K, Poole EL, Lau B, Voigt S, Kledal TN, Rosenkilde MM, and Sinclair JH (2017b) Targeting the latent cytomegalovirus reservoir with an antiviral fusion toxin protein. Nat Commun 8:14321.

Krishna BA, Wass AB, Sridharan R, and O'Connor CM (2020) The requirement for US28 during cytomegalovirus latency is independent of US27 and US29 gene expression. Front Cell Infect Microbiol 10:186.

Kuhn DE, Beall CJ, and Kolattukudy PE (1995) The cytomegalovirus US28 protein binds multiple CC chemokines with high affinity. Biochem Biophys Res Commun 211:325-330.

Kumar A, Tripathy MK, Pasquereau S, Al Moussawi F, Abbas W, Coquard L, Khan KA, Russo L, Algros MP, Valmary-Degano S, et al. (2018) The human cytomegalovirus strain DB activates oncogenic pathways in mammary epithelial cells. EBioMedicine 30:167-183.

Langemeijer EV, Slinger E, de Munnik S, Schreiber A, Maussang D, Vischer H, Verkaar F, Leurs R, Siderius M, and Smit MJ (2012) Constitutive $\beta$-catenin signaling by the viral chemokine receptor US28. PLoS One 7:e48935.

Li Y, Zhou C, Li J, Liu J, Lin L, Li L, Cao D, Li Q, and Wang Z (2018) Single domain based bispecific antibody, Muc1-Bi-1, and its humanized form, Muc1-Bi-2, induce potent cancer cell killing in muc1 positive tumor cells. PLoS One 13:e0191024.

Liang Y and Ganem D (2004) RBP-J (CSL) is essential for activation of the K14/ vGPCR promoter of Kaposi's sarcoma-associated herpesvirus by the lytic switch protein RTA. J Virol 78:6818-6826.

Liu C, Clark PA, Kuo JS, and Kalejta RF (2017) Human cytomegalovirus-infected glioblastoma cells display stem cell-like phenotypes. MSphere 2:e0137-e00217.

Liu G, Yu FX, Kim YC, Meng Z, Naipauer J, Looney DJ, Liu X, Gutkind JS, Mesr EA, and Guan KL (2015) Kaposi sarcoma-associated herpesvirus promotes tumorigenesis by modulating the Hippo pathway. Oncogene 34:3536-3546

Lollinga WT, de Wit RH, Rahbar A, Vasse GF, Davoudi B, Diepstra A, RiezebosBrilman A, Harmsen MC, Hillebrands JL, Söderberg-Naucler C, et al. (2017) Human cytomegalovirus-encoded receptor US28 is expressed in renal allografts and facilitates viral spreading in vitro. Transplantation 101:531-540.

López-Rodríguez DM, Kirillov V, Krug LT, Mesri EA, and Andreansky S (2019) A role of hypoxia-inducible factor 1 alpha in Murine Gammaherpesvirus 68 (MHV68) lytic replication and reactivation from latency. PLoS Pathog 15:e1008192.

Lückmann M, Amarandi RM, Papargyri N, Jakobsen MH, Christiansen E, Jensen LJ, Pui A, Schwartz TW, Rosenkilde MM, and Frimurer TM (2017) Structurebased discovery of novel US28 small molecule ligands with different modes of action. Chem Biol Drug Des 89:289-296.

Lyngaa R, Nørregaard K, Kristensen M, Kubale V, Rosenkilde MM, and Kledal TN (2010) Cell transformation mediated by the Epstein-Barr virus G protein-coupled receptor BILF1 is dependent on constitutive signaling. Oncogene 29:4388-4398.

Maciejewski JP and St Jeor SC (1999) Human cytomegalovirus infection of human hematopoietic progenitor cells. Leuk Lymphoma 33:1-13.

Margulies BJ, Browne H, and Gibson W (1996) Identification of the human cytomegalovirus G protein-coupled receptor homologue encoded by UL33 in infected cells and enveloped virus particles. Virology 225:111-125.

Margulies BJ and Gibson W (2007) The chemokine receptor homologue encoded by US27 of human cytomegalovirus is heavily glycosylated and is present in infected human foreskin fibroblasts and enveloped virus particles. Virus Res 123:57-71.

Martin D and Gutkind JS (2009) Kaposi's sarcoma virally encoded, G-protein-coupled receptor: a paradigm for paracrine transformation. Methods Enzymol 460:125-150

Mason GM, Poole E, Sissons JG, Wills MR, and Sinclair JH (2012) Human cytomegalovirus latency alters the cellular secretome, inducing cluster of differentiation (CD)4+ T-cell migration and suppression of effector function. Proc Natl Acad Sci USA 109:14538-14543.

Maussang D, Langemeijer E, Fitzsimons CP, Stigter-van Walsum M, Dijkman R, Borg MK, Slinger E, Schreiber A, Michel D, Tensen CP, et al. (2009) The human cytomegalovirus-encoded chemokine receptor US28 promotes angiogenesis and tumor formation via cyclooxygenase-2. Cancer Res 69:2861-2869.

Maussang D, Mujić-Delić A, Descamps FJ, Stortelers C, Vanlandschoot P, Stigtervan Walsum M, Vischer HF, van Roy M, Vosjan M, Gonzalez-Pajuelo M, et al (2013) Llama-derived single variable domains (nanobodies) directed against chemokine receptor CXCR7 reduce head and neck cancer cell growth in vivo. J Biol Chem 288:29562-29572.

Maussang D, Verzijl D, van Walsum M, Leurs R, Holl J, Pleskoff O, Michel D, van Dongen GA, and Smit MJ (2006) Human cytomegalovirus-encoded chemokine receptor US28 promotes tumorigenesis. Proc Natl Acad Sci USA 103:13068-13073. 
Melnick JL, Adam E, and DeBakey ME (1996) Cytomegalovirus and atherosclerosis. Arch Immunol Ther Exp (Warsz) 44:297-302.

Melnick JL, Petrie BL, Dreesman GR, Burek J, McCollum CH, and DeBakey ME (1983) Cytomegalovirus antigen within human arterial smooth muscle cells. Lancet 2:644-647.

Melnychuk RM, Streblow DN, Smith PP, Hirsch AJ, Pancheva D, and Nelson JA (2004) Human cytomegalovirus-encoded G protein-coupled receptor US28 mediates smooth muscle cell migration through Galpha12. J Virol 78:8382-8391.

Menotti L, Mirandola P, Locati M, and Campadelli-Fiume G (1999) Trafficking to the plasma membrane of the seven-transmembrane protein encoded by human herpesvirus 6 U51 gene involves a cell-specific function present in T lymphocytes. $J$ Virol 73:325-333.

Mesri EA, Cesarman E, and Boshoff C (2010) Kaposi's sarcoma and its associated herpesvirus. Nat Rev Cancer 10:707-719.

Michaelis M, Doerr HW, and Cinatl J (2009) The story of human cytomegalovirus and cancer: increasing evidence and open questions. Neoplasia 11:1-9.

Michel D, Milotić I, Wagner M, Vaida B, Holl J, Ansorge R, and Mertens T (2005) The human cytomegalovirus UL78 gene is highly conserved among clinical isolates, but is dispensable for replication in fibroblasts and a renal artery organ-culture system. J Gen Virol 86:297-306.

Michelson S, Dal Monte P, Zipeto D, Bodaghi B, Laurent L, Oberlin E, ArenzanaSeisdedos F, Virelizier JL, and Landini MP (1997) Modulation of RANTES production by human cytomegalovirus infection of fibroblasts. J Virol 71:6495-6500.

Miles TF, Spiess K, Jude KM, Tsutsumi N, Burg JS, Ingram JR, Waghray D, Hjorto GM, Larsen O, Ploegh HL, et al. (2018) Viral GPCR US28 can signal in response to chemokine agonists of nearly unlimited structural degeneracy. eLife 7:e35850.

Milne RS, Mattick C, Nicholson L, Devaraj P, Alcami A, and Gompels UA (2000) RANTES binding and down-regulation by a novel human herpesvirus- 6 beta chemokine receptor. J Immunol 164:2396-2404.

Mitchell DA, Xie W, Schmittling R, Learn C, Friedman A, McLendon RE and Sampson JH (2008) Sensitive detection of human cytomegalovirus in tumors and peripheral blood of patients diagnosed with glioblastoma. Neuro-oncol 10 $10-18$

Mokros T, Rehm A, Droese J, Oppermann M, Lipp M, and Höpken UE (2002) Surface expression and endocytosis of the human cytomegalovirus-encoded chemokine receptor US28 is regulated by agonist-independent phosphorylation. J Biol Chem 277:45122-45128.

Mollica Poeta V, Massara M, Capucetti A, and Bonecchi R (2019) Chemokines and chemokine receptors: new targets for cancer immunotherapy. Front Immunol 10: 379

Montaner S, Sodhi A, Ramsdell AK, Martin D, Hu J, Sawai ET, and Gutkind JS (2006) The Kaposi's sarcoma-associated herpesvirus G protein-coupled receptor as a therapeutic target for the treatment of Kaposi's sarcoma. Cancer Res 66:168-174.

Montaner S, Sodhi A, Servitja JM, Ramsdell AK, Barac A, Sawai ET, and Gutkind JS (2004) The small GTPase Rac1 links the Kaposi sarcoma-associated herpesvirus vGPCR to cytokine secretion and paracrine neoplasia. Blood 104:2903-2911.

Moorman NJ, Virgin HW 4th, and Speck SH (2003) Disruption of the gene encoding the gammaHV68 v-GPCR leads to decreased efficiency of reactivation from latency. Virology 307:179-190.

Morales-Sánchez A and Fuentes-Panana EM (2018) The immunomodulatory capacity of an epstein-barr virus abortive lytic cycle: potential contribution to viral tumorigenesis. Cancers (Basel) 10:98.

Moussawi FA, Kumar A, Pasquereau S, Tripathy MK, Karam W, Diab-Assaf M, and Herbein G (2018) The transcriptome of human mammary epithelial cells infected with the HCMV-DB strain displays oncogenic traits. Sci Rep 8:12574.

Murdoch C and Finn A (2000) Chemokine receptors and their role in inflammation and infectious diseases. Blood 95:3032-3043.

Nakano K, Tadagaki K, Isegawa Y, Aye MM, Zou P, and Yamanishi K (2003) Human herpesvirus 7 open reading frame U12 encodes a functional beta-chemokine receptor. $J$ Virol 77:8108-8115.

Nauclér CS, Geisler J, and Vetvik K (2019) The emerging role of human cytomegalovirus infection in human carcinogenesis: a review of current evidence and potential therapeutic implications. Oncotarget 10:4333-4347.

Nijmeijer S, Leurs R, Smit MJ, and Vischer HF (2010) The Epstein-Barr virusencoded G protein-coupled receptor BILF1 hetero-oligomerizes with human CXCR4, scavenges Goi proteins, and constitutively impairs CXCR4 functioning. J Biol Chem 285:29632-29641.

Noriega VM, Gardner TJ, Redmann V, Bongers G, Lira SA, and Tortorella D (2014) Human cytomegalovirus US28 facilitates cell-to-cell viral dissemination. Viruses 6 $1202-1218$.

O'Connor CM and Shenk T (2011) Human cytomegalovirus pUS27 G protein-coupled receptor homologue is required for efficient spread by the extracellular route but not for direct cell-to-cell spread. J Virol 85:3700-3707.

O'Connor CM and Shenk T (2012) Human cytomegalovirus pUL78 G protein-coupled receptor homologue is required for timely cell entry in epithelial cells but not fibroblasts. $J$ Virol 86:11425-11433.

Oberstein A and Shenk T (2017) Cellular responses to human cytomegalovirus infection: induction of a mesenchymal-to-epithelial transition (MET) phenotype. Proc Natl Acad Sci USA 114:E8244-E8253.

Oliveira SA and Shenk TE (2001) Murine cytomegalovirus M78 protein, a G proteincoupled receptor homologue, is a constituent of the virion and facilitates accumulation of immediate-early viral mRNA. Proc Natl Acad Sci USA 98:3237-3242.

Pati S, Cavrois M, Guo HG, Foulke JS Jr, Kim J, Feldman RA, and Reitz M (2001) Activation of NF-kappaB by the human herpesvirus 8 chemokine receptor ORF74: evidence for a paracrine model of Kaposi's sarcoma pathogenesis. J Virol 75: 8660-8673.

Paulsen SJ, Rosenkilde MM, Eugen-Olsen J, and Kledal TN (2005) Epstein-Barr virus-encoded BILF1 is a constitutively active G protein-coupled receptor. $J$ Virol 79:536-546.
Pearson GR (1993) Epstein-Barr virus and nasopharyngeal carcinoma. J Cell Biochem Suppl 17F:150-154.

Pontejo SM, Murphy PM, and Pease JE (2018) Chemokine subversion by human herpesviruses. J Innate Immun 10:465-478.

Prezeau L, Rives ML, Comps-Agrar L, Maurel D, Kniazeff J, and Pin JP (2010) Functional crosstalk between GPCRs: with or without oligomerization. Curr Opin Pharmacol 10:6-13.

Quinn LL, Zuo J, Abbott RJ, Shannon-Lowe C, Tierney RJ, Hislop AD, and Rowe M (2014) Cooperation between Epstein-Barr virus immune evasion proteins spreads protection from CD8+ T cell recognition across all three phases of the lytic cycle. PLoS Pathog 10:e1004322.

Radu O and Pantanowitz L (2013) Kaposi sarcoma. Arch Pathol Lab Med 137: 289-294

Rajasekaran D, Gröning S, Schmitz C, Zierow S, Drucker N, Bakou M, Kohl K Mertens A, Lue H, Weber C, et al. (2016) Macrophage migration inhibitory factorCXCR4 receptor interactions: evidence for partial allosteric agonism in comparison with CXCL12 chemokine. J Biol Chem 291:15881-15895.

Rakusan TA, Juneja HS, and Fleischmann WR Jr (1989) Inhibition of hemopoietic colony formation by human cytomegalovirus in vitro. $J$ Infect Dis 159:127-130.

Ramanan P and Razonable RR (2013) Cytomegalovirus infections in solid organ transplantation: a review. Infect Chemother 45:260-271.

Randolph-Habecker JR, Rahill B, Torok-Storb B, Vieira J, Kolattukudy PE, Rovin $\mathrm{BH}$, and Sedmak DD (2002) The expression of the cytomegalovirus chemokine receptor homolog US28 sequesters biologically active CC chemokines and alters IL8 production. Cytokine 19:37-46.

Ransohoff RM (2009) Chemokines and chemokine receptors: standing at the crossroads of immunobiology and neurobiology. Immunity 31:711-721.

Rasmussen SG, Choi HJ, Fung JJ, Pardon E, Casarosa P, Chae PS, Devree BT, Rosenbaum DM, Thian FS, Kobilka TS, et al. (2011) Structure of a nanobodystabilized active state of the $\beta(2)$ adrenoceptor. Nature 469:175-180.

Reid GE, Lynch JP 3rd, Weigt S, Sayah D, Belperio JA, Grim SA, and Clark NM (2016) Herpesvirus respiratory infections in immunocompromised patients: epidemiology, management, and outcomes. Semin Respir Crit Care Med 37:603-630.

Rosenbaum DM, Rasmussen SG, and Kobilka BK (2009) The structure and function of G-protein-coupled receptors. Nature 459:356-363.

Rosenkilde MM, Kledal TN, Bräuner-Osborne H, and Schwartz TW (1999) Agonists and inverse agonists for the herpesvirus 8-encoded constitutively active seventransmembrane oncogene product, ORF-74. J Biol Chem 274:956-961.

Rozan C, Cornillon A, Pétiard C, Chartier M, Behar G, Boix C, Kerfelec B, Robert B, Pèlegrin A, Chames P, et al. (2013) Single-domain antibody-based and linker-free bispecific antibodies targeting FcyRIII induce potent antitumor activity without recruiting regulatory T cells. Mol Cancer Ther 12:1481-1491.

Samanta M, Harkins L, Klemm K, Britt WJ, and Cobbs CS (2003) High prevalence of human cytomegalovirus in prostatic intraepithelial neoplasia and prostatic carcinoma. J Urol 170:998-1002.

Sandford G, Choi YB, and Nicholas J (2009) Role of ORF74-encoded viral G proteincoupled receptor in human herpesvirus 8 lytic replication. $J$ Virol 83:13009-13014.

Scholten DJ, Canals M, Maussang D, Roumen L, Smit MJ, Wijtmans M, de Graaf C, Vischer HF, and Leurs R (2012) Pharmacological modulation of chemokine receptor function. Br J Pharmacol 165:1617-1643.

Shah S, DeBerge M, Iovane A, Yan S, Qiu L, Wang JJ, Kanwar YS, Hummel M, Zhang ZJ, Abecassis MM, et al. (2020) MCMV dissemination from latently-infected allografts following transplantation into pre-tolerized recipients. Pathogens 9:607.

Sharma-Walia N, Raghu H, Sadagopan S, Sivakumar R, Veettil MV, Naranatt PP, Smith MM, and Chandran B (2006) Cyclooxygenase 2 induced by Kaposi's sarcoma-associated herpesvirus early during in vitro infection of target cells plays a role in the maintenance of latent viral gene expression. $J$ Virol 80:6534-6552.

Shelby BD, LaMarca HL, McFerrin HE, Nelson AB, Lasky JA, Sun G, Myatt L, Offermann MK, Morris CA, and Sullivan DE (2007) Kaposi's sarcoma associated herpesvirus G-protein coupled receptor activation of cyclooxygenase-2 in vascular endothelial cells. Virol $J$ 4:87.

Shen Y, Zhu H, and Shenk T (1997) Human cytomagalovirus IE1 and IE2 proteins are mutagenic and mediate "hit-and-run" oncogenic transformation in cooperation with the adenovirus E1A proteins. Proc Natl Acad Sci USA 94:3341-3345.

Shepard LW, Yang M, Xie P, Browning DD, Voyno-Yasenetskaya T, Kozasa T, and Ye RD (2001) Constitutive activation of NF-kappa B and secretion of interleukin-8 induced by the G protein-coupled receptor of Kaposi's sarcoma-associated herpesvirus involve G alpha(13) and RhoA. J Biol Chem 276:45979-45987.

Shnayder M, Nachshon A, Krishna B, Poole E, Boshkov A, Binyamin A, Maza I, Sinclair J, Schwartz M, and Stern-Ginossar N (2018) Defining the transcriptional landscape during cytomegalovirus latency with single-cell RNA sequencing. MBio 9:e0013-e00018.

Siew VK, Duh CY, and Wang SK (2009) Human cytomegalovirus UL76 induces chromosome aberrations. J Biomed Sci 16:107.

Sing GK and Ruscetti FW (1990) Preferential suppression of myelopoiesis in normal human bone marrow cells after in vitro challenge with human cytomegalovirus. Blood 75:1965-1973.

Sing GK and Ruscetti FW (1995) The role of human cytomegalovirus in haematological diseases. Baillieres Clin Haematol 8:149-163.

Slinger E, Langemeijer E, Siderius M, Vischer HF, and Smit MJ (2011) Herpesvirusencoded GPCRs rewire cellular signaling. Mol Cell Endocrinol 331:179-184.

Slinger E, Maussang D, Schreiber A, Siderius M, Rahbar A, Fraile-Ramos A, Lira SA Söderberg-Nauclér C, and Smit MJ (2010) HCMV-encoded chemokine receptor US28 mediates proliferative signaling through the IL-6-STAT3 axis. Sci Signal 3: ra58.

Smit MJ, Verzijl D, Casarosa P, Navis M, Timmerman H, and Leurs R (2002) Kaposi's sarcoma-associated herpesvirus-encoded $\mathrm{G}$ protein-coupled receptor ORF74 constitutively activates p44/p42 MAPK and Akt via G(i) and phospholipase C-dependent signaling pathways. J Virol 76:1744-1752. 
Sodhi A, Montaner S, Patel V, Zohar M, Bais C, Mesri EA, and Gutkind JS (2000) The Kaposi's sarcoma-associated herpes virus $\mathrm{G}$ protein-coupled receptor up-regulates vascular endothelial growth factor expression and secretion through mitogenactivated protein kinase and p38 pathways acting on hypoxia-inducible factor 1alpha. Cancer Res 60:4873-4880.

Sohy D, Parmentier M, and Springael JY (2007) Allosteric transinhibition by specific antagonists in CCR2/CXCR4 heterodimers. J Biol Chem 282:30062-30069.

Sohy D, Yano H, de Nadai P, Urizar E, Guillabert A, Javitch JA, Parmentier M, and Springael JY (2009) Hetero-oligomerization of CCR2, CCR5, and CXCR4 and the protean effects of "selective" antagonists. J Biol Chem 284:31270-31279.

Soroceanu L, Matlaf L, Bezrookove V, Harkins L, Martinez R, Greene M, Soteropoulos P, and Cobbs CS (2011) Human cytomegalovirus US28 found in glioblastoma promotes an invasive and angiogenic phenotype. Cancer Res 71:6643-6653.

Soroceanu L, Matlaf L, Khan S, Akhavan A, Singer E, Bezrookove V, Decker S, Ghanny S, Hadaczek P, Bengtsson H, et al. (2015) Cytomegalovirus immediateearly proteins promote stemness properties in glioblastoma. Cancer Res $\mathbf{7 5}$ : 3065-3076.

Spiess K, Fares S, Sparre-Ulrich AH, Hilgenberg E, Jarvis MA, Ehlers B, and Rosenkilde MM (2015a) Identification and functional comparison of seventransmembrane G-protein-coupled BILF1 receptors in recently discovered nonhuman primate lymphocryptoviruses. $J$ Virol 89:2253-2267.

Spiess K, Jeppesen MG, Malmgaard-Clausen M, Krzywkowski K, Dulal K, Cheng T, Hjortø GM, Larsen O, Burg JS, Jarvis MA, et al. (2015b) Rationally designed chemokine-based toxin targeting the viral G protein-coupled receptor US28 potently inhibits cytomegalovirus infection in vivo. Proc Natl Acad Sci USA 112 $8427-8432$

Spiess K, Jeppesen MG, Malmgaard-Clausen M, Krzywkowski K, Kledal TN, and Rosenkilde MM (2017) Novel chemokine-based immunotoxins for potent and selective targeting of cytomegalovirus infected cells. J Immunol Res 2017:4069260.

Staskus KA, Zhong W, Gebhard K, Herndier B, Wang H, Renne R, Beneke J, Pudney J, Anderson DJ, Ganem D, et al. (1997) Kaposi's sarcoma-associated herpesvirus gene expression in endothelial (spindle) tumor cells. J Virol 71:715-719.

Stegman JR and Margulies BJ (2017) The human cytomegalovirus chemokine receptor homolog encoded by US27. Virus Genes 53:516-521.

Stern L, Withers B, Avdic S, Gottlieb D, Abendroth A, Blyth E, and Slobedman B (2019) Human cytomegalovirus latency and reactivation in allogeneic hematopoietic stem cell transplant recipients. Front Microbiol 10:1186.

Streblow DN, Hwee YK, Kreklywich CN, Andoh T, Denton M, Smith P, Hart E, Broekel R, Pallett C, Rogers K, et al. (2015) Rat cytomegalovirus vaccine prevents accelerated chronic rejection in CMV-naïve recipients of infected donor allograft hearts. Am J Transplant 15:1805-1816.

Streblow DN, Kreklywich CN, Smith P, Soule JL, Meyer C, Yin M, Beisser P, Vink C, Nelson JA, and Orloff SL (2005) Rat cytomegalovirus-accelerated transplant vascular sclerosis is reduced with mutation of the chemokine-receptor R33. Am $J$ Transplant 5:436-442.

Streblow DN, Soderberg-Naucler C, Vieira J, Smith P, Wakabayashi E, Ruchti F, Mattison K, Altschuler Y, and Nelson JA (1999) The human cytomegalovirus chemokine receptor US28 mediates vascular smooth muscle cell migration. Cell 99: $511-520$

Streblow DN, Vomaske J, Smith P, Melnychuk R, Hall L, Pancheva D, Smit M, Casarosa P, Schlaepfer DD, and Nelson JA (2003) Human cytomegalovirus chemokine receptor US28-induced smooth muscle cell migration is mediated by focal adhesion kinase and Src. J Biol Chem 278:50456-50465.

Sultanova A, Cistjakovs M, Sokolovska L, Todorova K, Cunskis E, and Murovska M (2020) HHV-6 infection and chemokine RANTES signaling pathway disturbance in patients with autoimmune thyroiditis. Viruses 12:689.

Tadagaki K, Nakano K, and Yamanishi K (2005) Human herpesvirus 7 open reading frames U12 and U51 encode functional beta-chemokine receptors. J Virol 79: 7068-7076

Tadagaki K, Tudor D, Gbahou F, Tschische P, Waldhoer M, Bomsel M, Jockers R, and Kamal M (2012) Human cytomegalovirus-encoded UL33 and UL78 heteromerize with host CCR5 and CXCR4 impairing their HIV coreceptor activity. Blood 119:4908-4918.

Tadagaki K, Yamanishi K, and Mori Y (2007) Reciprocal roles of cellular chemokine receptors and human herpesvirus 7-encoded chemokine receptors, U12 and U51. $J$ Gen Virol 88:1423-1428.

Takeda M, Watanabe S, Katano H, Noguchi K, Sato Y, Kojima S, Miura T, Majima R, Yamada S, and Inoue N (2018) Roles of GP33, a Guinea pig cytomegalovirusencoded G protein-coupled receptor homolog, in cellular signaling, viral growth and inflammation in vitro and in vivo. PLoS Pathog 14:e1007487.

Teo WH, Chen HP, Huang JC, and Chan YJ (2017) Human cytomegalovirus infection enhances cell proliferation, migration and upregulation of EMT markers in colorectal cancer-derived stem cell-like cells. Int J Oncol 51:1415-1426.

Thompson MP and Kurzrock R (2004) Epstein-Barr virus and cancer. Clin Cancer Res 10:803-821.

Tierney RJ, Shannon-Lowe CD, Fitzsimmons L, Bell AI, and Rowe M (2015) Unexpected patterns of Epstein-Barr virus transcription revealed by a high throughput PCR array for absolute quantification of viral mRNA. Virology $\mathbf{4 7 4}$ 117-130.
Tu CC and Spencer JV (2014) The DRY box and C-terminal domain of the human cytomegalovirus US27 gene product play a role in promoting cell growth and survival. PLoS One 9:e113427.

van Senten JR, Bebelman MP, Fan TS, Heukers R, Bergkamp ND, van Gasselt P, Langemeijer EV, Slinger E, Lagerweij T, Rahbar A, et al. (2019) The human cytomegalovirus-encoded G protein-coupled receptor UL33 exhibits oncomodulatory properties. J Biol Chem 294:16297-16308.

van Senten JR, Bebelman MP, van Gasselt P, Bergkamp ND, van den Bor J, Siderius M, and Smit MJ (2020a) Human cytomegalovirus-encoded G protein-coupled receptor UL33 facilitates virus dissemination via the extracellular and cell-to-cell route. Viruses 12:594.

van Senten JR, Fan TS, Siderius M, and Smit MJ (2020b) Viral G protein-coupled receptors as modulators of cancer hallmarks. Pharmacol Res 156:104804.

Vieira J, Schall TJ, Corey L, and Geballe AP (1998) Functional analysis of the human cytomegalovirus US28 gene by insertion mutagenesis with the green fluorescent protein gene. $J$ Virol 72:8158-8165.

Virgin HW 4th, Latreille P, Wamsley P, Hallsworth K, Weck KE, Dal Canto AJ, and Speck SH (1997) Complete sequence and genomic analysis of murine gammaherpesvirus 68. J Virol 71:5894-5904.

Vischer HF, Hulshof JW, Hulscher S, Fratantoni SA, Verheij MH, Victorina J, Smit MJ, de Esch IJ, and Leurs R (2010) Identification of novel allosteric nonpeptidergic inhibitors of the human cytomegalovirus-encoded chemokine receptor US28. Bioorg Med Chem 18:675-688.

Vischer HF, Nijmeijer S, Smit MJ, and Leurs R (2008) Viral hijacking of human receptors through heterodimerization. Biochem Biophys Res Commun 377 : 93-97.

Vischer HF, Siderius M, Leurs R, and Smit MJ (2014) Herpesvirus-encoded GPCRs: neglected players in inflammatory and proliferative diseases? Nat Rev Drug Discov 13:123-139.

Vischer HF, Vink C, and Smit MJ (2006) A viral conspiracy: hijacking the chemokine system through virally encoded pirated chemokine receptors. Curr Top Microbiol Immunol 303:121-154

Vomaske J, Melnychuk RM, Smith PP, Powell J, Hall L, DeFilippis V, Früh K, Smit M, Schlaepfer DD, Nelson JA, et al. (2009) Differential ligand binding to a human cytomegalovirus chemokine receptor determines cell type-specific motility. PLoS Pathog 5:e1000304

Vp Ribeiro R, Ku T, Ferreira VH, Galasso M, Moshkelgosha S, Michaelsen V, Wang A, Ali A, Ramadan K, Gomes BM, et al. (2020) Targeting latent human cytomegalovirus (CMV) with a novel fusion toxin protein during ex vivo lung perfusion. $J$ Heart Lung Transplant 39:S83.

Wagner S, Arnold F, Wu Z, Schubert A, Walliser C, Tadagaki K, Jockers R, Mertens T, and Michel D (2012) The 7-transmembrane protein homologue UL78 of the human cytomegalovirus forms oligomers and traffics between the plasma membrane and different intracellular compartments. Arch Virol 157:935-949.

Waldhoer M, Kledal TN, Farrell H, and Schwartz TW (2002) Murine cytomegalovirus (CMV) M33 and human CMV US28 receptors exhibit similar constitutive signaling activities. J Virol 76:8161-8168.

Weber C, Kraemer S, Drechsler M, Lue H, Koenen RR, Kapurniotu A, Zernecke A and Bernhagen J (2008) Structural determinants of MIF functions in CXCR2mediated inflammatory and atherogenic leukocyte recruitment. Proc Natl Acad Sci USA 105:16278-16283.

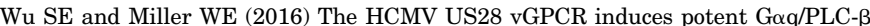
signaling in monocytes leading to increased adhesion to endothelial cells. Virology 497:233-243.

Yang TY, Chen SC, Leach MW, Manfra D, Homey B, Wiekowski M, Sullivan L, Jenh $\mathrm{CH}$, Narula SK, Chensue SW, et al. (2000) Transgenic expression of the chemokine receptor encoded by human herpesvirus 8 induces an angioproliferative disease resembling Kaposi's sarcoma. J Exp Med 191:445-454.

Zhang J, Wang J, Wood C, Xu D, and Zhang L (2005) Kaposi's sarcoma-associated herpesvirus/human herpesvirus 8 replication and transcription activator regulates viral and cellular genes via interferon-stimulated response elements. $J$ Virol $\mathbf{7 9}$ : $5640-5652$

Zhen Z, Bradel-Tretheway B, Sumagin S, Bidlack JM, and Dewhurst S (2005) The human herpesvirus $6 \mathrm{G}$ protein-coupled receptor homolog U51 positively regulates virus replication and enhances cell-cell fusion in vitro. $J$ Virol $\mathbf{7 9}$ : 11914-11924.

Zhu D, Pan C, Sheng J, Liang H, Bian Z, Liu Y, Trang P, Wu J, Liu F, Zhang CY, et al. (2018) Human cytomegalovirus reprogrammes haematopoietic progenitor cells into immunosuppressive monocytes to achieve latency. Nat Microbiol 3 503-513.

Zuo J, Currin A, Griffin BD, Shannon-Lowe C, Thomas WA, Ressing ME, Wiertz EJ, and Rowe M (2009) The Epstein-Barr virus G-protein-coupled receptor contributes to immune evasion by targeting MHC class I molecules for degradation. PLoS Pathog 5:e1000255.

Zuo J, Quinn LL, Tamblyn J, Thomas WA, Feederle R, Delecluse HJ, Hislop AD, and Rowe M (2011) The Epstein-Barr virus-encoded BILF1 protein modulates immune recognition of endogenously processed antigen by targeting major histocompatibility complex class I molecules trafficking on both the exocytic and endocytic pathways. J Virol 85:1604-1614. 